STATE OF ILLINOIS

DEPARTMENT OF REGISTRATION AND EDUCATION

Some Fern-Like Fructifications and Their Spores from the Mazon Creek Compression Flora of Illinois (Pennsylvanian)

H. W. Pfefferkorn

R. A. Peppers

T. L. Phillips

CIRCULAR 463

ILLINOIS STATE GEOLOGICAL SURVEY URBANA, ILLINOIS 61801 John C. Frye, Chief 
Digitized by the Internet Archive in 2012 with funding from

University of Illinois Urbana-Champaign

http://archive.org/details/somefernlikefruc463pfef 


\title{
SOME FERN-LIKE FRUCTIFICATIONS AND THEIR SPORES FROM THE MAZON CREEK COMPRESSION FLORA OF ILLINOIS (PENNSYLVANIAN)
}

\author{
H. W. Pfefferkorn, ${ }^{1}$ R. A. Peppers, ${ }^{1}$ and T. L. Phillips ${ }^{2}$
}

\section{ABSTRACT}

Some species of fertile foliage and their spores are described from ironstone nodules of the Francis Creek Shale Member of the Carbondale Formation (Pennsylvanian) of Illinois. The Francis Creek Shale is Desmoinesian and in European terminology probably Westphalian D in age.

Spores in situ from the fructifications were examined by light microscopy and scanning electron microscopy and compared with dispersed spores. The forms described are listed below.

Megafossil

STELLATHECA Danzé

Stellatheca latiloba Danzé

Stellatheca ornata (Lesquereux) comb. nov. MYRIOTHECA Zeiller

Myriotheca scaberrima (Lesquereux) Sellards Myriotheca arnoldi sp. nov.

? Punctatisporites, ? Calamospora CORYNEPTERIS Bailey

Corynepteris (ex Alloiopteris) cf. erosa ASTEROTHECA Presl

Asterotheca (ex Pecopteris) sp. 1

Asterotheca (ex Pecopteris) sp. 2$\}$

Asterotheca (ex Pecopteris) sp. 3$\}$

Asterotheca (ex Pecopteris) sp. 4 \}

Asterotheca (ex Pecopteris) cf. miltoni

SCOLECOPTERIS Zenker

? Scolecopteris sp. 1

? Scolecopteris sp. 2
Camptotriletes triangularis

?Apiculatasporites, ? Microreticulatisporites, ? Foveosporites, ? Cyclogranisporites

Name of comparable dispersed spore

Apiculatisporis setulosus

Laevigatosporites minutus

Punctatisporites minutus

Cyclogranisporites aureus

Punctatisporites $\mathrm{sp}$.

Laevigatosporites globosus

${ }^{1}$ Illinois State Geological Survey, Urbana, Illinois 61801

Department of Botany, University of Illinois, Urbana, Illinois 61801 


\section{INTRODUCTION}

Pennsylvanian plant flossils from the Mazon Creek area are better known than any other compression flora of Illinois. Fertile specimens from the flora have been described by Lesquereux (1866-1884), Sellards (1902, 1903), Darrah (1936, 1937, 1938, 1970), Arnold (1938), Schopf (1948), Andrews and Mamay (1948), Kosanke (1955), Chaloner (1956), Langford (1958, 1963), Delevoryas (1964), Taylor (1967), and Taylor and Eggert (1969a, b). The following fructification genera of ferns and pteridosperms have been reported from Mazon Creek: Asterotheca Presl, Codonotheca Sellards, Corynepteris Bailey, Crossotheca Zeiller, Hymenotheca Potonié, Myriotheca Zeiller, Oligocarpia Goeppert, Ptychocarpus Weiss, Radstockia Kidston, Renaultia Stur, Schopfitheca Delevoryas, Senftenbergia Corda, Wittleseya Newberry, and Zeilleria Kidston.

In addition to the above miospore fructifications, two rather poorly defined genera, Sorocladus and Staphylopteris, were reported by Lesquereux (1880). Inferences of the occurrences of other fertile genera from Mazon Creek are based only on sterile foliage (Langford, 1958, 1963). In formal descriptions the practice of applying generic names of fructifications to sterile foliage is as misleading as using sterile foliage names for fructifications.

There are two nomenclatural systems for foliage fossils: one is a system of form-species and form-genera of foliage; the other recognizes organ-species and genera of fructifications, which can often be related to a family. One species of fertile foliage may belong to two genera, one in each system, and geologically oriented paleobotanists consider it helpful to express both genera. In certain cases one form-species can be the foliage of either of two organ genera; for example, Pecopteris miltoni can be the foliage of Asterotheca miltoni or Mokrawia alberti (Knopp, 1933). Of the many nomenclatural practices in use we regard that one used by Remy and Remy (1968) in, for example, Asterotheca (ex form-genus Pecopteris) lamuriana as one of the clearest means of the generic designation of a specimen of fertile foliage. A shorter version is adopted for fertile fronds, where possible, in this study, for example, Asterotheca (ex Pecopteris) lamuriana. This kind of designation should be applicable in any case where the form-genus is determinable and well known. We suggest that only the form-genus and species be used for specimens of sterile fronds even if fructifications are known from other apparently identical foliage specimens.

The spores found in situ in fructifications may be compared to genera and species of dispersed spores but not assigned to them, because a separate binomial system has been adopted for dispersed spores, which are found in rock macerations without direct evidence of their natural affinities.

This study was undertaken to gain more data about the correlation of spores and megafossils. Only those fructification specimens which promised to yield new data were selected. These include the genus Stellatheca, previously not reported from North America; a new species, Myriotheca arnoldi; and other species of the genera Myriotheca, Corynepteris, Asterotheca, and ? Scolecopteris. Spores isolated from these fructifications have been examined by light and scanning electron microscopy and compared with Punctatisporites, Calamospora, Cyclogranisporites, Apiculatasporites, Apiculatisporis, Microreticulatisporites, Camptotriletes, and Laevigatosporites.

Information obtained from this study supports the conclusion that differences exist between the flora of the No. 2 Coal and the flora represented by the Mazon Creek compression fossils from the overlying Francis Creek Shale (Peppers and Pfefferkorn, 1970). 


\section{Location and Stratigraphy}

All specimens described in this study occur in ironstone (sideritic) nodules from the Francis Creek Shale Member in the vicinity of Mazon Creek, Coal City, or Wilmington in Will and Grundy Counties, Illinois (text fig. 1). These fossils are generally referred to as the Mazon Creek flora. The Francis Creek Shale immediately overlies the Colchester (No. 2) Coal at the base of the Carbondale Formation, Kewanee Group, Pennsylvanian. In American time-stratigraphic classification, the Francis Creek Shale is in the middle part of the Desmoinesian Series; it is in zone no. 10 of the floral zones of Read and Mamay (1964). In European time stratigraphy this interval is probably in the Westphalian D (Jongmans, 1937; Bode, 1958, 1960); however, the presence of some plants of Stephanian character led Noé $(1925,1930,1936)$ to place the interval in the Stephanian A.

\section{Materials and Methods}

The Mazon Creek fossils were deposited in rapidly accumulating mud. Ironstone nodules formed around the fossil plants shortly after deposition. In

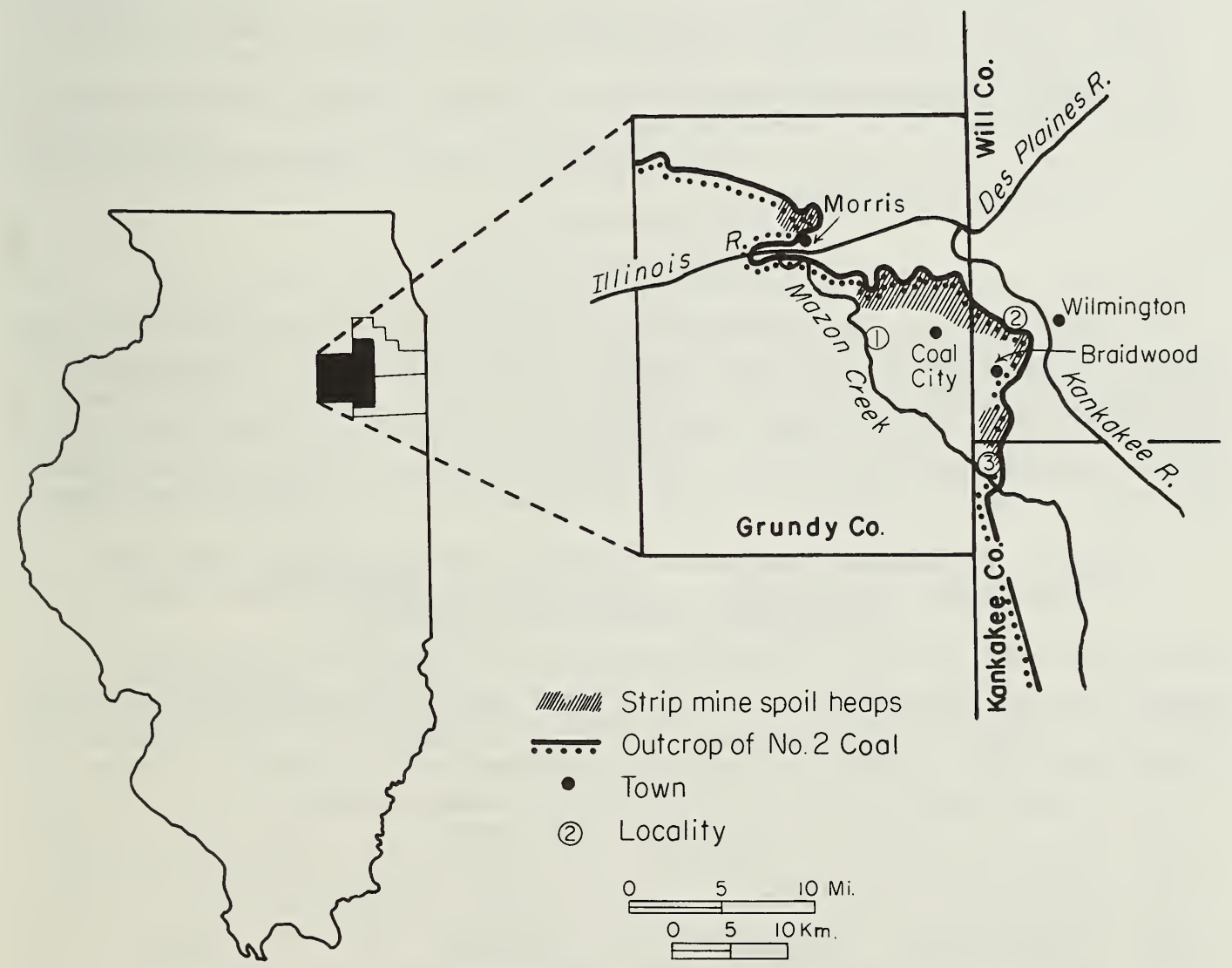

Text fig. 1 - Localities of the Mazon Creek flora in Grundy, Will, and Kankakee Counties, Illinois. 1 - Mazon Creek proper (creek bed), locality of all older collections. 2 - Spoil heaps where the Langford collection was made. 3 - Pit 11 , newest collecting locality; no material from this locality has been used in this report. 
this manner fructifications were fossilized without major compactional flattening. Plant tissues decayed for the most part, but occasionally a carbonaceous film was preserved. Spores are well preserved, undistorted or collapsed, and not mineral filled. The spores are pale yellow to brown, and clearing is not necessary for optical study.

Spores were mechanically removed from sporangial cavities and covered with absolute alcohol for one or two minutes on a microscope slide until the alcohol was nearly, but not entirely, evaporated. In this way the air which fills the spores in dried specimens was removed and the mounting medium could enter the spores. Then the spores were mounted in Canada balsam mixed with xylene and alcohol. For scanning electron microscopy, spores or spore masses were mounted with glue on aluminum studs, exposed for 12 hours to the vapor of crystalline osmium tetroxide, and coated in vacuum, first with carbon, then with gold, and again with carbon (G. E. Pfefferkorn, 1969, 1970).

Prefix designations of specimen numbers indicate the source collections and locations of materials studied:

USNM - United States National Museum, Washington, D. C. (including Lacoe Collection). The National Museum is the depository of all spore slides prepared in this study.

ISM - Illinois State Museum, Springfield, Illinois (including part of Langford Collection).

C - Carr Collection, University of Illinois Natural History Museum, Urbana, Illinois.

PP or UP - Field Museum of Natural History, Chicago, Illinois (including part of Langford Collection).

\section{Descriptive Terminology}

The terms used for the designation of different parts of the lamina from the smaller to the larger unit are: lobe, pinnule, pinna, and frond. In Stellatheca the smallest ultimate laminate unit of foliage is termed a pinnule in accordance with the usage by Danzé (1956). Because the same unit may be described as a lobe in other foliage specimens, a uniform designation is employed (table 1 and text fig. 2) with " $n$ " indicating the ultimate order of lateral veins, $n-1$ the pen-

TABLE 1 - DESCRIPTIVE TERMTNOLOGY SUGGESTED FOR STELLATHECA (AND OTHER SPHENOPTERIS-LIKE FOLIAGE). (THE ORDER DESIGNATION REMAINS STABLE ALTHOUGH THE INTERPRETATION MAY VARY.)

\begin{tabular}{|c|c|c|c|c|}
\hline \multirow{2}{*}{ Order } & \multicolumn{2}{|c|}{ As applied } & \multicolumn{2}{c|}{ Other interpretation possibility } \\
\cline { 2 - 4 } & Axis & Lamina & Axis & Lamina \\
\hline
\end{tabular}

$\begin{array}{cllll}\mathrm{n} & \text { lateral vein } & \text { ultimate lateral } & \text { vein } \\ \mathrm{n}-1 & \text { midvein } & \text { pinnule } & \text { lateral vein } & \text { lobe } \\ \mathrm{n}-2 & \text { rachis }(\mathrm{n}-2) & \begin{array}{c}\text { ultimate } \\ \text { pinna }(\mathrm{n}-2)\end{array} & \text { midvein } & \text { pinnule } \\ \mathrm{n}-3 & \text { rachis }(\mathrm{n}-3) & \begin{array}{c}\text { penultimate } \\ \text { pinna }(\mathrm{n}-3)\end{array} & \text { rachis }(\mathrm{n}-3) & \begin{array}{c}\text { ultimate } \\ \text { pinna }(\mathrm{n}-3)\end{array}\end{array}$




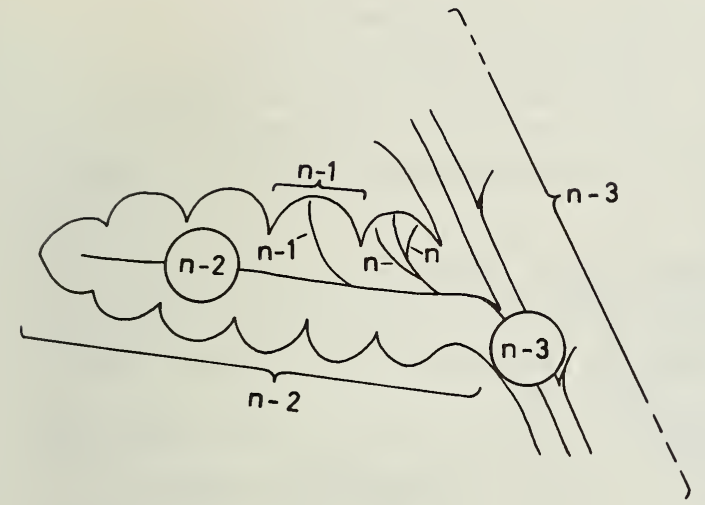

Text fig. 2 - Proposed designation of different parts of the lamina of Stellatheca and Sphenopteris. ultimate, and continuing with $\mathrm{n}-2$ and $\mathrm{n}-3$, according to $\mathrm{H}$. W. Pfefferkorn (in press). The lamina has the same designation as its main vascular strand and in this way elements which are morphologically equivalent will have the same " $n$ " designation even if their outlines appear to be lobes on one specimen, or part of a specimen, and pinnules on another. The use of a descending order in the numbering and describing of foliage elements in fossil ferns has been used by many authors (summarized by Raabe, 1966). The terminology proposed in this paper differs by including midveins and lateral veins in the count of orders.

The formal designation proposed here is especially helpful in the formgenus Sphenopteris and a few other highly dissected forms, such as Stellatheca, which show a high variability in the division of their foliage. It has not been applied to the other genera in this report because there exists no problem in the designation of the laminate units in the form-genera Alloiopteris and Pecopteris. In Myriotheca it would be quite helpful but is at present not applicable because the veins are not visible in the specimens.

\section{Acknowledgments}

The specimens for this study were kindly loaned to the senior author by Dr. F. M. Hueber and Dr. S. H. Mamay, Washington, D. C., Mr. R. L. Leary, Spring field, and Dr. E. S. Richardson, Chicago. The electron micrographs of the spores were made by $\mathrm{Dr}$. R. Blaschke, Münster, Germany, whose help is very much appreciated. Some of the figures were specially prepared by Margaret S. Whaley. Thanks are due to Dr. C. A. Arnold, Ann Arbor, for helpful discussions at an early stage of the project.

\section{Genus STELLATHECA Danzé, 1956}

Stellatheca is regarded as a fern fructification. According to Danzé (1956), the genus Stellatheca can be described as follows. The sori of Stellatheca consist of 6 to 15 free sporangia, with most of the sporangia forming a circle or an ellipse around 1 to 3 centrally located sporangia. Sori are attached to the abaxial laminar surface of pecopterid to sphenopterid pinnules between the midvein and the margin or at the margin near the end of a lateral vein. Sporangia are ovoid, and a longitudinal dehiscence is found on the outer face of peripheral sporangia. Despite the lack of an annulus, a terminal zone of isodiametric cells resembles an apical plate oriented toward the margin of the soral circle. The sporangial wall consists of longitudinal rows of elongate cells, and sporangia are attached to a receptacle by a slightly tapered base.

To the above may be added spore data from this study: Spores are trilete and subcircular to circular. Laesurae are usually indistinct and extend threequarters the length of the spore radius. Ornamentation consists of conate projections. 
Stratigraphic range: Lower Westphalian C to Westphalian D

Geographic distribution: Northern France and Illinois (U.S.A.)

The two species of Stellatheca that have been described, $\underline{S}$. latiloba (Danzé, 1956) and $\underline{S}$. ornata (Lesquereux, 1884) comb. nov. Pfefferkorn, p. 8, are grossly separable by the smaller wings on the pinna axis $(n-3)$ in $\underline{S}$. ornata, which is known only from Illinois.

\section{Stellatheca latiloba Danzé, 1956 \\ pl. 1, figs. 1-5; pl. 2, figs. 1-10; pl. 3, figs. 1-4}

1880 Pecopteris lyratifolia Goeppert, in Lesquereux 1879 (Atlas), 1880 (text), p. 259, pl. 48, figs. 4-4c.

1884 Pecopteris ornata Lesquereux, p. 760, pl. 111, fig. 30a (exclusive of figs. 30 and $30 \mathrm{~b}$, which belong to Stellatheca ornata).

1956 Stellatheca latiloba Danzé, p. 284-287, pl. 43, figs. 2-2b, pl. 44 , figs. 1,2 .

Four specimens of Stellatheca latiloba were examined, two with both halves present and two with only one half of the ironstone nodule available. All are from Mazon Creek, Illinois.

USNM 13385 (figured by Lesquereux, 1884) and USNM 13386 (Lacoe Coll. 1008a). USNM 13382 (Lacoe Coll. 643a) (figured by Lesquereux, 1880).

USNM 13383 and 13384 (Lacoe Coll. 910a). Determined by Lesquereux as Pecop-

teris stellata Lesquereux, 1880, but does not agree with his figure and description.

Description. - Pinnules $(n-1)$ are semicircular in outline and continuous basally with the wings of the pinna axis $(n-2)$. Pinnules are 2 to $3.5 \mathrm{~mm}$ wide and 1 to $4.5 \mathrm{~mm}$ long, excluding the laminar wing of the pinna axis $(n-2)$, which is 1 to $2.5 \mathrm{~mm}$ wide. The angle of pinnule $(\mathrm{n}-1)$ attachment to the pinna axis $(\mathrm{n}-2)$ is less than $75^{\circ}$; the pinnules are attached along their entire bases and touch each other laterally at the base. Sori are apparently marginal or very near the margin, and the laminar margin sometimes extends over sori. Midveins $(n-1)$ and lateral veins ( $\mathrm{n})$ are usually indistinct.

Pinnae ( $n-2)$ are tongue-shaped, distally tapered, and fused basally with the laminar wings of the pinna axis $(n-3)$. Pinnae $(n-2)$ are 18 to $25 \mathrm{~mm}$ long, including a laminar wing, and 5 to $13 \mathrm{~mm}$ wide. Pinnae $(\mathrm{n}-2)$ touch laterally at the basal attachment but do not overlap, and the angle of attachment is $45^{\circ}-90^{\circ}$.

Pinnae $(\mathrm{n}-3)$ are more than $70 \mathrm{~mm}$ long and are $40 \mathrm{~mm}$ wide, and there are nine pinnae $(n-2)$ or more on each side. The winged lamina of the pinna axis $(\mathrm{n}-2)$ is $4.0 \mathrm{~mm}$ wide. Two distinct ridges, apparently indicating the vascular strand on the upper part of the pinna axis $(n-3)$, are $0.4 \mathrm{~mm}$ apart.

Sori are crowded together in groups on or near the laminar margin. Smaller sori occur near the pinnule tip. A sorus consists of 6 to 15 free sporangia, with most of the sporangia forming a circle or an ellipse around 1 to 3 central sporangia. The long axis of elliptical sori is parallel with the laminar margin (text fig. 3); there are usually 4 (3 to 6$)$ sori on a pinnule $(n-1)$ and none on the winged part of any pinna axis $(n-2, n-3)$. Sori are 1.0 to $1.5 \mathrm{~mm}$ in diameter, and sporangia are 0.3 to $0.4 \mathrm{~mm}$ in diameter. The sporangia show an elongated indentation on the lower abaxial side (shown in one sorus in text fig. $3 \mathrm{~A}$ ).

The trilete spores are subcircular to circular in equatorial outline (pl. 2, figs. 4-10). Laesurae extend three-quarters the length of the spore radius and 


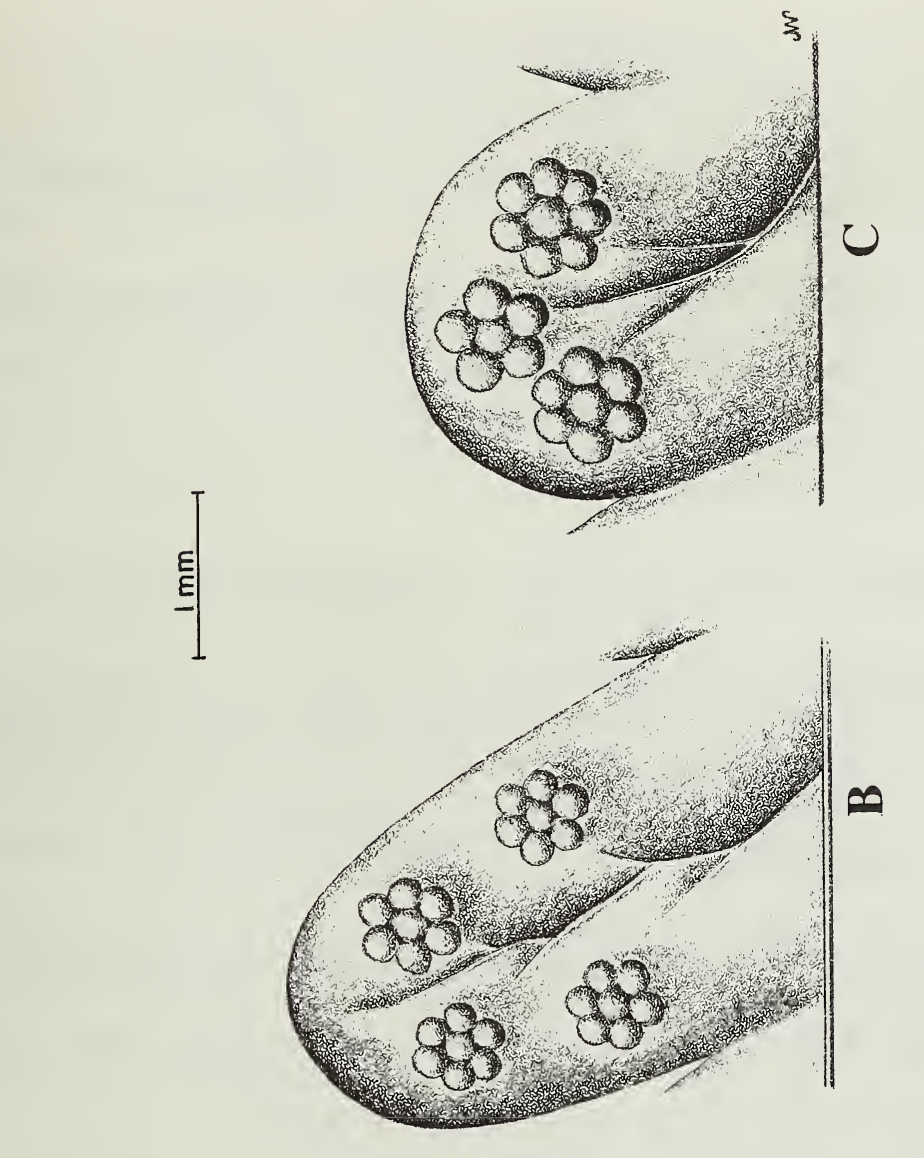

¿

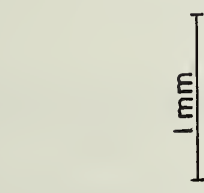

†

0
$\stackrel{2}{\pi}$
0
2

范

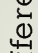

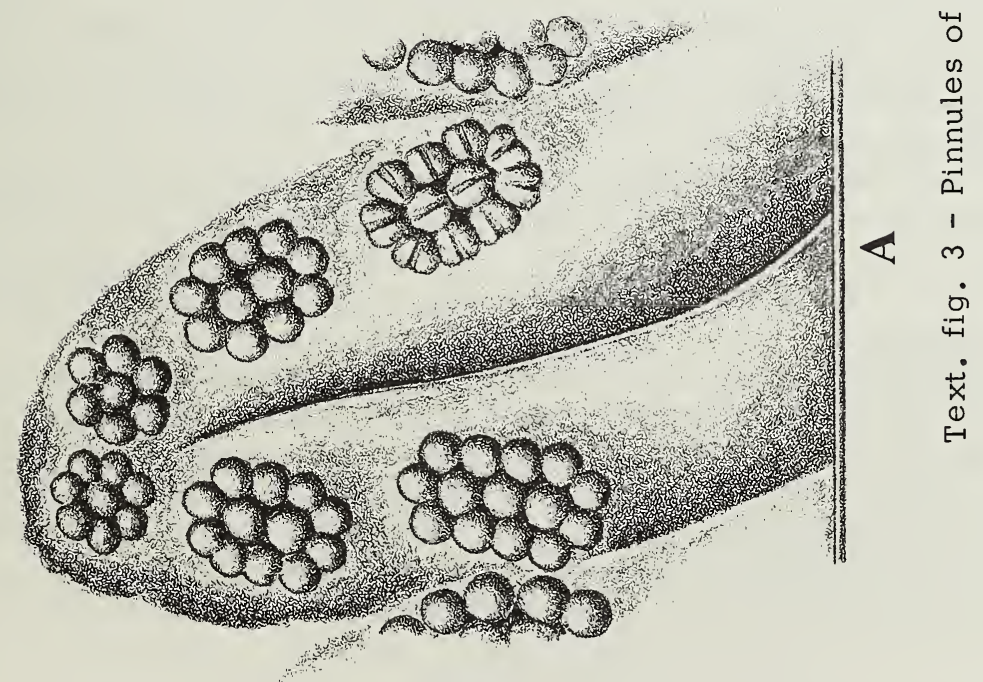


are usually indistinct because of secondary folds. Labra are up to $1 \mu \mathrm{m}$ wide. Ornamentation consists of closely spaced projections, intermediate between conate and papillate, with gradually tapered round ends. Projections are about $1 \mu \mathrm{m}$ wide basally and 1.0 to $1.5 \mu \mathrm{m}$ long; several projections sometimes are joined to form small ridges, and ridges, in turn, are interconnected on some spores to form a punctate or loosely reticulate pattern (pl. 2, figs. 5, 6). The spore wall is less than $1 \mu \mathrm{m}$ thick.

A considerable difference in spore diameters was observed in preparations from the two halves of one specimen (USNM 13385 and USNM 13386). Thirty-two spore diameters (slide USNM 13385) indicate a range of 19 to $30 \mu \mathrm{m}$, with an average of $25 \mu \mathrm{m}$; thirty-five spore diameters (slide USNM 13386) show a range of 29 to $37 \mu \mathrm{m}$, with an average of $33 \mu \mathrm{m}$. The range for all the samples is 19 to 37 $\mu \mathrm{m}$, with an average diameter of $29 \mu \mathrm{m}$.

Stellatheca ornata (Lesquereux, 1884) comb. nov. Pfefferkorn pl. 3, fig. $5 ; \mathrm{pl} .4$

1884 Pecopteris ornata Lesquereux, p. 760, pl. 111 , figs. 30, 30b

(exclusive of figure $30 \mathrm{a}$, which belongs to $\underline{\mathrm{S}}$. latiloba).

1958 Pecopteris halli Lesquereux, in Langford, p. 172-173, fig. 299 (ISM 15830).

1963 Pecopteris solida Lesquereux, in Langford, p. 215, fig. 827 (ISM 15830).

Three specimens were examined, each with part and counterpart: USNM 13387, USNM 13388 (Lacoe Coll. 1008b) from Mazon Creek, Illinois. Figured by Lesquereux (1884), holotype;

ISM 15548a, b (Langford Coll. $246 \mathrm{p}-1$ ) from near Wilmington, Will County, Illinois;

ISM 15830 from near Wilmington, Will County, Illinois.

Description. - Pinnules (n-1) are semicircular or tongue-shaped, sometimes only lobe-like as in ISM 15548 (pl. 4, fig. 4). The pinnules, up to $3 \mathrm{~mm}$ long and $2 \mathrm{~mm}$ wide, usually have indistinct midveins $(\mathrm{n}-1)$ and lateral veins $(\mathrm{n})$. Pinnules $(n-1)$ are attached along the entire base at an angle of about $50^{\circ}$ and are basally fused (text fig. 4).

Pinnae $(\mathrm{n}-2)$ are $16 \mathrm{~mm}$ long and $5 \mathrm{~mm}$ wide on USNM 13387-8 and $18 \mathrm{~mm}$ long and $6 \mathrm{~mm}$ wide on ISM 15548. Pinnae $(\mathrm{n}-2)$ are inserted at less than $60^{\circ}$.

Pinnae $(\mathrm{n}-3)$, which are more than $70 \mathrm{~mm}$ long and about $30 \mathrm{~mm}$ wide, bear pinnae $(\mathrm{n}-2) 7$ to $10 \mathrm{~mm}$ apart. The pinna axis $(\mathrm{n}-3)$ is 1.4 to $2.0 \mathrm{~mm}$ wide and only slightly winged.

Superficial sori consist of 6 to 12 free sporangia, with most of the sporangia forming a circle or an ellipse around one or two central sporangia. Sori are attached at the end of lateral veins near the laminar margin and are 0.8 to $1.2 \mathrm{~mm}$ in diameter. There are usually three ( 2 to 5$)$ sori on a pinnule $(n-1)$; no sori occur on the laminar wing of the pinna axis $(n-3)$. Sporangia are 0.2 to $0.3 \mathrm{~mm}$ in diameter, and the wall pattern consists of elongate cells in longitudinal rows parallel to the long axes of sporangia. No spores were present in the investigated specimens.

\section{Discussion}

In describing the compression specimens of Stellatheca latiloba from the northern French coal basin, Danzé (1956) mentioned its similarity to Oliqocarpia 


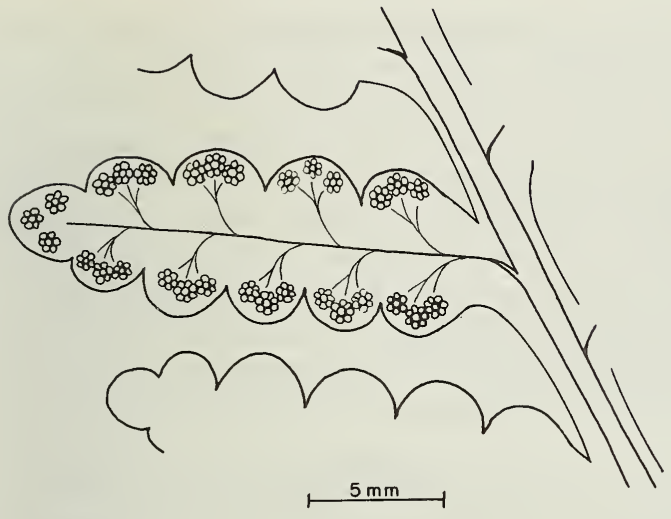

Text fig. 4 - Fertile pinna of Stellatheca ornata. gutbieri. In the Mazon Creek flora this similarity is not obvious, because sporangia of Oligocarpia are often filled with rock matrix. From the monograph on Oligocarpia by Abbott (1954) it becomes clear, however, that there are several similarities. Although the form, shape, and position of the sori are similar (fig. 7-10 of Abbott, 1954) in both genera, the sori appear to be slightly more regularly arranged in Stellatheca. Stellatheca has 6 to 15 sporangia per sorus, while Oligocarpia has 4 to 17 , with 4 or 5 sporangia being the most common number. One to three sporangia occur in the center of larger sori of oligocarpia and in all

sori of Stellatheca. While there is a possibility of overlap of Stellatheca and Oligocarpia based on some soral characters, there is a distinct difference between the variable appearance of the pinnules of Oligocarpia and the regular outline of the pinnules of Stellatheca. The main difference between the genera is the apparent dissimilarity of the sporangial wall. The annulus of Oligocarpia is much more clearly defined than anything which could be called an annulus in Stellatheca.

The sporangia of $\underline{S}$. latiloba were considered exannulate by Danzé (1956). The wall pattern consists of rows of elongate cells and an apical plate of isodiametric cells. This description resembles that of sporangia of Discopteris Stur, 1883: some authors interpreted them as exannulate, and others regarded the apical plate as an annulus. A reinvestigation of type specimens of Discopteris revealed that the lateral cell walls constituted a massive annulus and that there was an apical plate (H. W. Pfefferkorn, in press). A longitudinal groove observed in sporangia of Stellatheca in Mazon Creek specimens is interpreted as a region of dehiscence. As in Discopteris there is a two-ridged appearance on the largest pinna axis $(n-3)$, which may indicate an $\mathrm{H}$ - or $\mathrm{U}$-shaped vascular strand.

The spores in Oligocarpia are minutely punctate, and in Stellatheca spores show a strong ornamentation. The ornamentation is probably a real difference although the spore size range is quite similar $(29$ to $38 \mu \mathrm{m}$ in oligocarpia and 19 to $37 \mu \mathrm{m}$ in Stellatheca).

Stellatheca and Tedelea (Eggert and Taylor, 1966) possess several similarities. The marginal position of the sori is the same. In Tedelea the lateral veins fork only once and each branch bears one sorus. In Stellatheca a similar arrangement can occur in very small or young pinnules but normally a lateral vein is forked twice and gives rise to three sori. The differences between the two genera are, however, more numerous. While Tedelea has occasionally solitary sporangia and usually 2 to 7 sporangia per sorus, Stellatheca has 6 to 15. The sori, as well as the sporangia within a sorus, of Stellatheca have a much more regularly arranged appearance. The spores are entirely different in their ornamentation. The foliage in the two genera is somewhat but not very different, judging from the reconstruction of Eggert and Taylor (1966).

In the specimens described from Mazon Creek there is some superficial similarity between Stellatheca and Asterotheca in the kind of preservation. Asterotheca, however, has no central sporangia in a sorus and has smaller pinnae, smaller pinnules, and fewer sporangia in a sorus. 
Lesquereux apparently was aware that his Pecopteris ornata, $\underline{\text { p. lyratifolia, }}$ and $\underline{P}$. Stellata formed a natural group (Lesquereux, 1884, p. 760), and his mention of Pecopteris stellata in this group further suggests that the drawing and description of $\underline{P}$. stellata may be incorrect and that the taxon may belong to Stellatheca. However, it cannot be transferred to $\underline{S}$. latiloba without reinvestigation of the type, whose location is unknown. Lesquereux (1880, pl. 48, figs. 5, 5a, 5b) also figured a sterile foliage specimen which has some similarity to Stellatheca latiloba as described here, but there is presently no basis for recognizing it as the sterile frond. The lobes are longer and narrower than in $\underline{S}$. latiloba and Lesquereux compared it with Sphenopteris lyratifolia, which has been transferred to Callipteris (Jongmans and Dijkstra, 1958) and is certainly not congeneric with Stellatheca.

The major difference between the two species of Stellatheca is that the pinna axis $(n-3)$ of $\underline{S}$. latiloba has a wide wing while the axis $(n-3)$ of $\underline{S}$. ornata has no wing or only a small one. Considering the small number and small size of specimens available for examination, the possibility exists that both winged and unwinged pinnae could occur on the same frond. Spore data on $\underline{S}$. ornata are lacking, thus preventing spore comparisons.

The variation in soral position in Stellatheca is rather difficult to establish. According to Danzé's (1956) drawing and description, the sori of $\underline{\text { S }}$ latiloba are clearly located between the midvein and the margin; however, his photographs and our specimens seem to indicate that sori are very near the margin or are marginal. This discrepancyoccurs because part of the lamina is often not preserved and the sori or only parts of the sori form the preserved margin. This type of preservation led to the interpretation of a toothed margin by Langford (1958, 1963). Sori are strictly confined to pinnules $(n-1)$, although the pinnule may have the size and shape of a lobe. The sori are attached near a lateral vein ending, and the number of sori per pinnule $(n-1)$ generally increases from two to six with the size of the pinnule (text fig. 3). The number of sporangia per sorus is largest at the base of large pinnules $(n-1)$ and smallest at the tip of pinnules $(n-1)$. The largest sori are elliptical with the long axis parallel to the laminar margin and have three sporangia in a row surrounded by 12 others. The smallest sori are circular, with one sporangium surrounded by five others (text fig. 5).

An exact correlation between spores of Stellatheca latiloba and described dispersed spore taxa was not found. If found dispersed, the spores with separate coni probably conform most closely to Apiculatasporites (Ibrahim) Smith and Butterworth, 1967. Spores with punctate or reticulate exines probably would be assigned to Microreticulatisporites (Knox) Potonié and Kremp, 1954, or to Foveosporites Balme, 1957.
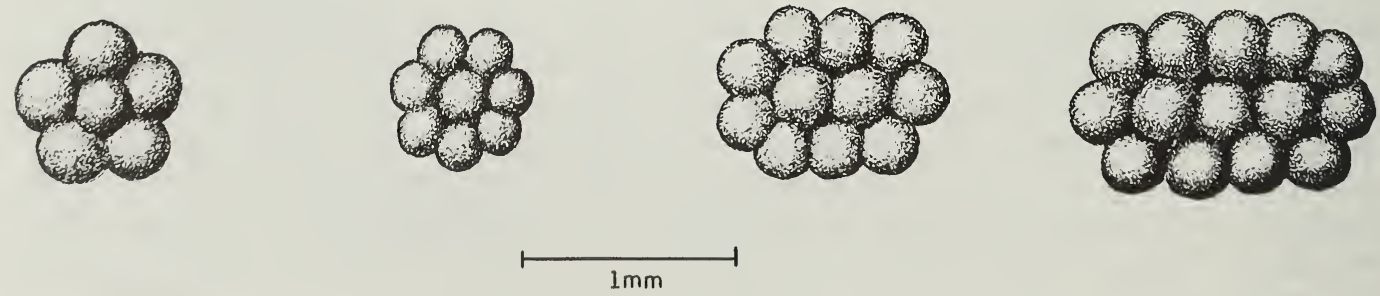

Text fig. 5 -Variation of sori of Stellatheca latiloba. 
Spores probably belonging to the same species as those of $\underline{S}$. latiloba have been recorded (Peppers, in progress) from several coals in the Mattoon Formation in the Illinois Basin. These are of special interest because of considerable variation in the development of a reticulate sculpture. Except for the larger size ( 37 to $61 \mu \mathrm{m}$ ) of Apiculatasporites casperatus Merendez and Azcuy, 1969, this species compares rather closely with spores of Stellatheca latiloba. Doubinger and Rauscher (1966) described and illustrated a species, Foveosporites insculptus Playford var. minor, which compares rather closely with the punctate or reticulate forms from Stellatheca latiloba. They also described a species identified as Apiculatisporis (?) globosus Butterworth and Williams, 1958, which shows similarities to the non-reticulate spores of $\underline{S}$. latiloba. However, specimens of Apiculatisporis globosus illustrated by Butterworth and Williams appear to have larger and more widely spaced cones than those of Doubinger and Rauscher. The spores described by Doubinger and Rauscher, however, come from strata of Viséan age and are considerably older than the Mazon Creek flora.

Since the ornamentation of the spores from our fructification might be considered granulose by some workers, an attempt was made to compare these spores with species of Cyclogranisporites. Of these spores, $\underline{C}$. leopoldi (Kremp) Potonié and Kremp, 1955, is probably the most similar to the spores of Stellatheca latiloba. Potonié and Kremp (1955) noted that the grana of $\underline{C}$. leopoldi are mostly rounded on the ends or weakly conical, but no mention was made of fusion of the ornaments. Spores that Smith and Butterworth (1967) assigned to Cyclogranisporites cf. minutus Bharadwaj, 1957, are also somewhat like the spores of Stellatheca latiloba.

The size and variation in fusion of sculptural elements in the spores of Stellatheca are similar to those found in spores of Botryopteris from coal balls by Phillips and Rosso (1970).

Genus MYRIOTHECA Zeiller, 1883

\section{Synonym: Polytheca H. Potonié, 1900}

Myriotheca is an easily identifiable genus, which bears free, ovoid, sessile sporangia in a non-soral, acrostichoid manner, covering the entire lower surface of sphenopterid or pecopterid pinnules. The sporangia are considered exannulate (Kidston, 1923), but as in Stellatheca, an apical plate and longitudinal dehiscence have been described (Danzé, 1956).

The following spore data can be added to the above generic summary: Spores are either trilete, circular in transverse plane, laevigate, and 70 to $91 \mu \mathrm{m}$ in diameter or trilete, triangular, rugulate, and 23 to $35 \mu \mathrm{m}$ in diameter.

Stratigraphic range: Westphalian B to Lower Permian.

Geographic distribution: Illinois and Pennsylvania (U.S.A.); Nova Scotia (Canada); Pas-du-Calais (Northern France); Derbyshire, Nottingham, and Yorkshire (England); Thuringia (Germany).

Two species of Myriotheca, M. scaberrima (Lesquereux) Sellards, 1902, and $\underline{M}$. arnoldi sp. nov. Pfefferkorn (p. 15), are known from the United States and four from Europe (table 2). The genus can be divided into two distinct groups. One group is represented by $\underline{M}$. desaillyi Zeiller, 1883, and $\underline{M}$. scaberrima, which are characterized by small sporangia $(0.25$ to $0.4 \mathrm{~mm})$, many sporangia per pinnule (50), and small, triangular, rugulose-verrucate spores (20 to $35 \mu \mathrm{m}$ ). The other group, 


\section{TABLE 2 - COMPARISON OF THE SPECIES OF MYRIOTHECA (FROM DIFFERENT SOURCES CITED IN TEXT)}

\begin{tabular}{|c|c|c|c|c|c|c|}
\hline Myriotheca & $\begin{array}{l}\text { Size of } \\
\text { sporangi- } \\
\text { um (mm) }\end{array}$ & $\begin{array}{l}\text { No. of } \\
\text { spo- } \\
\text { rangia } \\
\text { per } \\
\text { pinnule }\end{array}$ & Age & $\begin{array}{c}\text { Conti- } \\
\text { nent }\end{array}$ & Spore genus & $\begin{array}{l}\text { Size of } \\
\text { spores } \\
(\mu \mathrm{m})\end{array}$ \\
\hline desaillyi & 0.25 & 50 & Westphalian C & Eur. & (verrucate exine) & (unknown) \\
\hline scaberrima & 0.4 & $40-50$ & Westphalian D & N.Am. & Camptotriletes & $23-35$ \\
\hline monomakhoffi & 0.75 & 30 & Westphalian C & Eur. & (unknown) & (unknown) \\
\hline anglica & $0.5-0.75$ & 20 & Westphalian B & Eur. & ? Punctatisporites & $70-82$ \\
\hline arnoldi & $1.0-1.4$ & 35 & Westphalian D & N.Am. & Punctatisporites & $71-91$ \\
\hline permica & 0.5 & $\begin{array}{l}\text { (un- } \\
\text { known) }\end{array}$ & $\begin{array}{l}\text { Autunian } \\
\text { (Permian) }\end{array}$ & Eur. & (unknown) & (unknown) \\
\hline
\end{tabular}

which includes M. anglica Kidston, 1923, M. arnoldi sp. nov. (p. 15), M. permica Remy, 1954, and probably M. monomakhoffi Danzé, 1956, is characterized by large sporangia $(0.5$ to $1.4 \mathrm{~mm}), 30$ sporangia per pinnule, and large, circular, smooth spores $(70$ to $90 \mu \mathrm{m})$. In the future it might become necessary to distinguish these two groups as subgenera or separate genera.

Myriotheca has been considered a microspore-bearing pteridosperm structure by Kidston (1923) and a fern fructification by Remy (1954) and Danzé (1956). The spores appear to be fern-like, but the systematic position of Myriotheca remains unsettled.

Myriotheca scaberrima (Lesquereux, 1870) Sellards, 1902

$$
\text { pl. 5, figs. 1-7 }
$$

1870 Sphenopteris scaberrima Lesquereux, p. 408; pl. 15, figs. 1, 2.

1902 Myriotheca scaberrima (Lesquereux) Sellards, p. 199, pl. 7, figs. $5,5 a-c$.

1958 Myriotheca scaberrima (Lesquereux) in Langford, p. 277, fig. 508. Specimens: ISM 15728a, b (Langford Coll.)

$$
\text { PP } 2575
$$

PP 4759

Description. - The frond is quadripinnate and has triangular-shaped laminate pinnules which are up to $5 \mathrm{~mm}$ long and $2.5 \mathrm{~mm}$ wide and which are attached along the broad bases. Larger pinnules are lobed, somewhat constricted basally, and completely covered by sporangia on the abaxial side. There are 4 to 5 pinnules on each side of the pinnae. Pinnae are up to $14 \mathrm{~mm}$ long and $9 \mathrm{~mm}$ wide. The pinna axis is $0.6 \mathrm{~mm}$ wide, striate, and flexuous. Two ridges can be seen on the axis but only near the base. 
Non-soral sporangia are equally distributed on the lower laminar surface, and there are 40 to 50 sporangia on a pinnule (text fig. 6A). Sporangia are free, globose, sessile, and $0.4 \mathrm{~mm}$ in diameter.

The trilete spores are triangular to rounded triangular in equatorial outline. The corners are well rounded and the interradial sides are straight to slightly convex or, rarely, concave. Laesurae extend about two-thirds the length of the spore radius (about $12 \mu \mathrm{m}$ ), and sutures are distinct, open, and simple. The exine is unornamented in the area of the trilete marking. Ornamentation is found mostly on the distal face and consists of low rugulate projections. Fifty to seventy percent of the distal surface is covered by rugulae that are 4 to $6 \mu \mathrm{m}$ wide and extend up to $1.8 \mu \mathrm{m}$ beyond the margin, which has a scalloped appearance. Some specimens show development of larger rugulae near the corners. Rugulae are commonly shingle-like, rising gently above the spore surface and ending abruptly at its highest elevation. Twelve to fifteen arcs project beyond the margin. The spore wall is about $1.5 \mu \mathrm{m}$ thick. The diameters (46 specimens) range from 23 to $35 \mu \mathrm{m}$, with an average of $28 \mu \mathrm{m}$.

Discussion.- As sporae dispersae, the spores of Myriotheca scaberrima are correlated with Camptotriletes triangularis Peppers, 1970. The spores of Myriotheca scaberrima are smaller, thicker, and more coarsely ornamented than those of $\underline{C}$. triangularis ( 36 to $49 \mu \mathrm{m}$ in diameter). However, these discrepancies may be attributed to differences in preservation, in preparation for study, or perhaps in maturity. Converrucosisporites armatus (Dybova and Jachowicz) Smith and Butterworth (1967) is somewhat similar but is coarser and has a verrucose exine. Camptotriletes triangularis has been observed in strata between the Colchester (No. 2) Coal and Summum (No. 4) Coal, but it is rare.

Sellards (1902), the first paleobotanist to describe spores in situ from the Mazon Creek flora, discovered triangular spores having concave sides and diameters of 36 to $40 \mu \mathrm{m}$ in Myriotheca scaberrima. No remarks on the ornamentation of the exine were given. The spores of $\underline{M}$. desaillyi were described without illustration by Potonié (1967) from a slide preparation by Kidston. These spores, which were considered immature, are subtriangular to circular and flatly verrucate.

The present location of the holotype of Myriotheca scaberrima is unknown. It was found on shale from Morris, which is in the mining area around Mazon Creek. Therefore the stratum typicum probably would be equivalent to the Francis Creek Shale. The specimen described by Sellards (1902) is in the collection at Yale University. Sellards (1902) noted that his specimen differed from Lesquereux's description in that it lacked hairs on the pinnule-bearing axis. However, Lesquereux's description referred mainly to the pinnae-bearing axis and the "verrucose points" can only "indistinctly [be] seen on some part of the secondary branches [pinnule-bearing axes] " (Lesquereux, 1870, p. 408). Therefore, there is no contradiction and the determination is correct. The third specimen was figured by Langford (1958) and was investigated by the authors. It is covered with a thin film of white mineral matter, which obscures the spores. When covered with xylene, some of the spores float off. Cell patterns of the sporangia cannot be seen. The sporangia were apparently round with a very smooth surface. Two other specimens are in the collection of the Field Museum, Chicago.

Myriotheca scaberrima is similar to $\underline{M}$. desaillyi. The only difference is that the sporangia of $\mathrm{M}$. scaberrima are larger. As both species are based on a small number of specimens, they might prove to be conspecific when more specimens are found. Myriotheca scaberrima and M. desaillyi are clearly different from the other species, which have larger sporangia and larger and differently ornamented spores. 


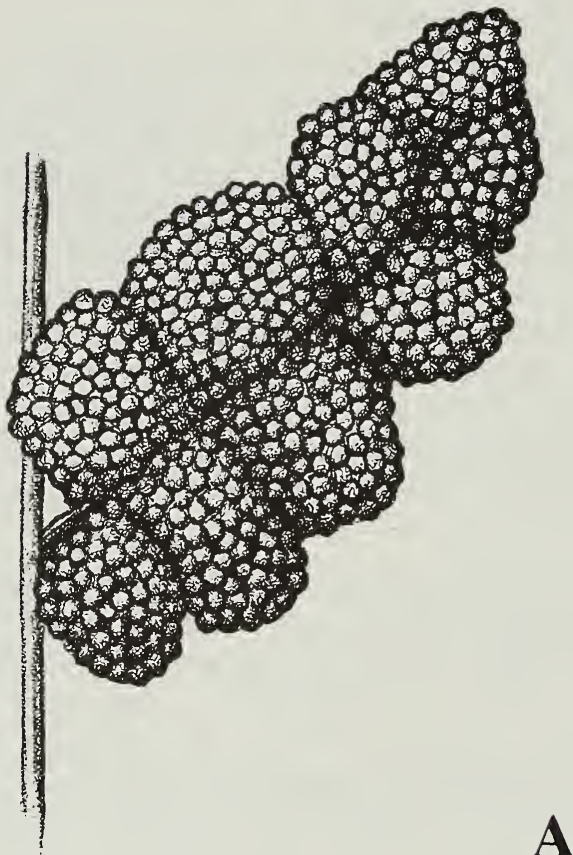

A
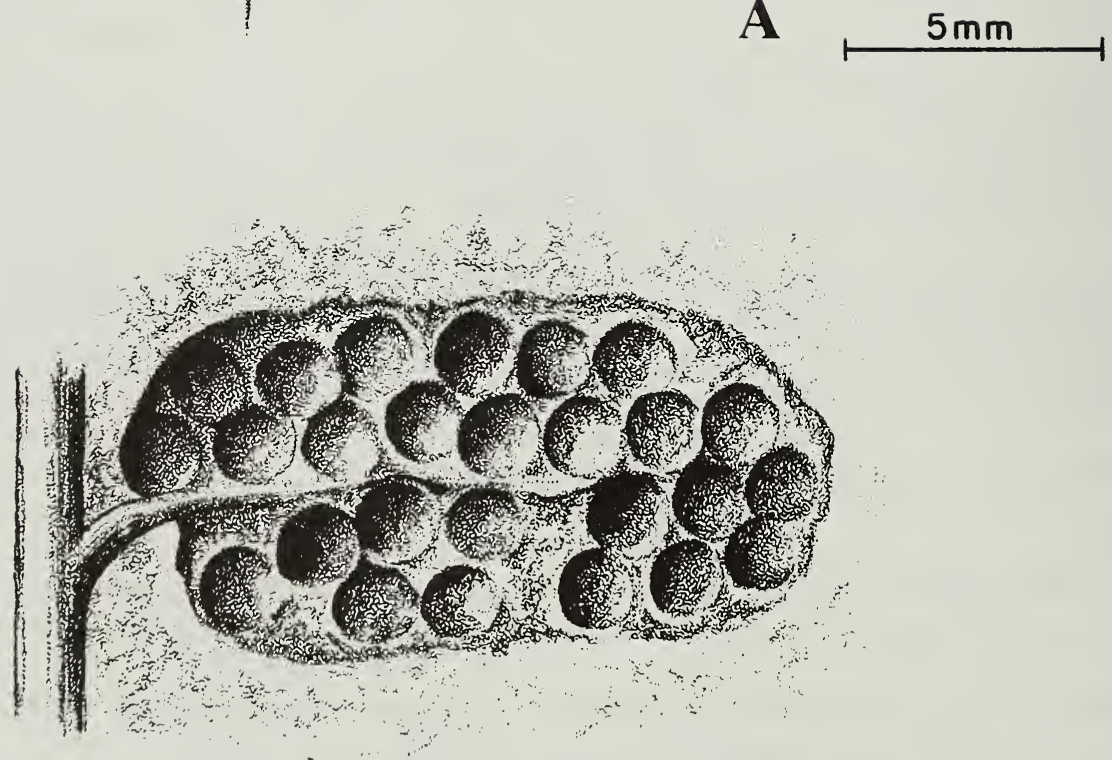

Text fig. 6 - A - Pinna of Myriotheca scaberrima and B - Pinnule of $\underline{M}$. arnoldi sp. nov. Pfefferkorn. 
Myriotheca arnoldi Pfefferkorn sp. nov.

Holotype: pl. 6, figs. 4-6, 8-9; ISM 15383 a and b (Langford Coll.).

Synchron-Paratype: pl. 6, fig. 1-3, 7; USNM 43714 a and b.

Stratum typicum: Francis Creek Shale Member above Colchester (No. 2) Coal Mem-

ber. Carbondale Formation, Desmoinesian Series, Westphalian D.

Locus typicus: Near Wilmington, Will County, Illinois .

Derivatio nominis: The new species is named in honor of Professor Chester A.

Arnold in recognition of his contributions to our knowledge of Paleozoic plants.

Diagnosis. - The frond is pinnately divided, probably in several orders, but only the last one is preserved. The pinnules are up to $12 \mathrm{~mm}$ long and $6 \mathrm{~mm}$ wide. The shape of the lamina is not recognizable but is somewhat sphenopteroid. The pinnules are covered by sporangia on the abaxial side. The axis shows a weak longitudinal striation and is slightly winged.

Sporangia are free, round, sessile, and 1.0 to $1.4 \mathrm{~mm}$ in diameter. There are about 35 sporangia on one pinnule; owing to the lobation of the pinnules, there is a tendency toward the occurrence of some groupings, made up of about eight sporangia. This grouping does not constitute the formation of sori.

Spores are radial, trilete, and circular in transverse plane, and were originally spherical. The trilete marking is distinct, the suture is simple, and the rays extend about two-thirds the length of the spore radius, or about $26 \mu \mathrm{m}$. The rays are of equal length. The exine is laevigate. The spore wall is 3 to $4 \mu \mathrm{m}$ thick, and the diameters of the spores (29 measurements) vary from a maximum of $91 \mu \mathrm{m}$ to a minimum of $71 \mu \mathrm{m}$, with a mean of $79 \mu \mathrm{m}$.

Discussion. - Myriotheca arnoldi has the largest sporangia and pinnules so far known in the genus; in other characteristics it is somewhat similar to $\underline{M}$. anglica, $\underline{\mathbf{M}}$. monomakhoffi and $\underline{\mathrm{M}}$. permica. The grouping of the sporangia in M. arnoldi appears to be distinctive, because the midrib of the pinnule is not covered by sporangia (text fig. 6B).

It is assumed that the foliage of $\underline{\mathrm{M}}$. arnoldi was Sphenopteris-like, because the veins are bipinnatifid and not stiff or regular. They bear some resemblance to Sphenopteris tridactylites (Lesquereux, 1880, pl. 55, figs. $9 \mathrm{a}-\mathrm{b}$ ).

As dispersed spores, those of Myriotheca arnoldi would be assigned to Punctatisporites or perhaps Calamospora. The spores have not been correlated with any named species of Punctatisporites or Calamospora, but except for thicker spore coats, the spores are similar to Calamospora sp. 1 (Peppers, 1970) from the Cardiff Coal. Spores reported from sporangia of Myriotheca anglica (Kidston, 1923) are very similar to those from $\underline{\mathrm{M}}$. arnoldi.

Genus CORYNEPTERIS Bailey, 1860

The fructification genus Corynepteris was early recognized as belonging to the zygopterid ferns. Even though the genus is well defined, the synonymy is 
quite extensive (Jongmans, 1957, p. 181). Sterile foliage is called Alloiopteris H. Potonié, 1897, and fructifications are called Corynepteris. Daber (1955) has suggested Saccopteris Stur, 1883, a younger synonym of Corynepteris, as the name for the entire plant.

The description below is based on one fertile specimen, part and counterpart (C 10814), from Mazon Creek, Illinois. The sori were covered by the carbonaceous film of the lamina, which was removed in order to obtain spores. The soral structure was not observable in detail, but there is no doubt about the generic assignment to this rather homogeneous genus.

\section{Corynepteris (ex Alloiopteris) cf. erosa (Gutbier) Kidston 1887 pl. 7, figs. 1-6}

Description. - The preserved part of the pinna is $6 \mathrm{~cm}$ long and $5.5 \mathrm{~cm}$ wide with both sides incomplete. Twelve lateral pinnae on each side are more than $2.8 \mathrm{~cm}$ long and $4 \mathrm{~mm}$ wide. One of the basal pinnules (anadromic?) is aphleboid (pl. 7, fig. 2).

Spores are trilete and circular in equatorial outline and have secondary folds. Laesurae are straight and extend three-fourths the length of the spore radius. The commissure is usually distinct and the labra are up to $1.5 \mu \mathrm{m}$ wide. The proximal and distal faces are covered with widely spaced spines and setae up to $3 \mu \mathrm{m}$ long and $1.5 \mu \mathrm{m}$ wide. Extending beyond the spore outline are 25 to 35 projections. The spore wall is 1.5 to $3.0 \mu \mathrm{m}$ thick. The diameters of 26 specimens range from 38 to $80 \mu \mathrm{m}$, with an average of $55 \mu \mathrm{m}$.

Discussion. - The specimen described above is most similar to Alloiopteris erosa because it has a few sharp indentations on pinnules and the pinnules are separated only near their tips. A. angustissima, which is similar to C 10814 in some respects, has smaller pinnules that are clearly separated from each other. Specimen C 10814 somewhat resembles $\underline{A}$. cristata, but aphleboid pinnules are lacking in that species (Nemejc, 1938).

The spores of Corynepteris cf. erosa are correlated with Apiculatisporis setulosus (Kosanke) Potonié and Kremp, 1955, and are compared with the holotype and other specimens found in Illinois. A. Cf. setulosus of Potonié and Kremp (1955) is apparently coarser and more densely ornamented than $\underline{A}$. setulosus. A. setulosus is a minor constituent in the spore floras but ranges throughout Pennsylvanian strata of the Illinois Basin. Corynepteris cf. erosa is also very rare.

Spores in situ from three other species of Corynepteris have been described. Kidston (1923) illustrated and described the spores of $\underline{C}$. sternbergii as circular, triradiate, papillose, and 55 to $58 \mu \mathrm{m}$ in diameter. From a separate preparation made from Kidston's material, Potonié (1967) interpreted the ornamentation of the spores as conate. The specimen of $\mathrm{C}$. sternbergii examined by Brush and Barghoorn $(1964,1965)$ bore triradiate, thick, psilate or finely foveolate spores 50 to $57 \mu \mathrm{m}$ in diameter. Moore $(1946,1965)$ found triradiate, spinose spores having "an annular wing" in a fertile specimen identified as Corynepteris. R. and W. Remy (1957) reported that the spores derived from C. silesiaca R. and W. Remy, 1955, are 70 to $80 \mu \mathrm{m}$ in diameter and have long trilete rays and a granulose exine. Potonié (1962) concluded that the exines of the Remys' specimens are covered with verrucae rather than grana and compared them with Verrucosisporites verrucosus (Ibrahim) Ibrahim, 1933. From present information, the spores of Corynepteris 
are radially trilete, circular in transverse plane, of medium (about 40 to $80 \mu \mathrm{m}$ ) size and thickness, and ornamented with papillate to conate or small verrucose projections.

\section{Genus ASTEROTHECA Presl, 1845}

Five specimens of Asterotheca-like fructifications were selected for this study because they show the same type of spore preservation as other fertile specimens studied in this paper. All investigated specimens are preserved in ironstone nodules from the Mazon Creek area. Macroscopic descriptions are given in table 3 . The spores are discussed in the following text. Specimens tentatively identified as $\underline{\text { Scolecopteris }}$ are described in the next section.

\section{Asterotheca (ex Pecopteris) sp. 1 and sp. 2 pl. 8, figs. $1-7$}

Description. - The spores of Asterotheca (ex Pecopteris) sp. 1 (PP 15338) and sp. 2 (USNM 14212) are monolete, bilaterally symmetrical, and elliptical to bean-shaped in transverse plane. The laesurae are distinct, straight, commonly open, and one-half to two-thirds the length of the long axis; the labra are $1 \mu \mathrm{m}$ or less on either side of the commissure. The exine is covered with grana $1 \mu \mathrm{m}$ or less in diameter, which are barely visible at the spore margin. The spore wall is less than $1 \mu \mathrm{m}$ thick. Spore diameters from PP 15338 (30 specimens) show a maximum of $21.8 \times 14.0 \mu \mathrm{m}$, a mean of $18.2 \times 12.4 \mu \mathrm{m}$, and a minimum of $15.6 \times 9.4$ $\mu \mathrm{m}$. Spore diameters from USNM 14212 (30 specimens) range from $14.6 \times 9.4 \mu \mathrm{m}$ to $20 \times 11.7 \mu \mathrm{m}$, with an average of $16.8 \times 10.6 \mu \mathrm{m}$.

Comparison. - Spores are correlated with Laevigatosporites minutus (Ibrahim) Schopf, Wilson, and Bentall, 1944. In the Illinois Basin Laevigatosporites minutus occurs throughout the Pennsylvanian except in the Caseyville Formation. It is most common in the Spoon and Carbondale Formations.

Asterotheca (ex Pecopteris) sp. 3 and sp. 4 pl. 9, figs. 1-6; pl. 10, figs. $1-4 ;$ pl. 11, fig. 4

Description. - The spores of Asterotheca (ex Pecopteris) sp. 3 (USNM 13287 ) and $\underline{A}$. (ex Pecopteris) sp. 4 (C 10797) are radially symmetrical, trilete, and originally spherical. Abundant secondary folds commonly obscure the trilete suture. Laesurae are straight and simple. Two laesurae, which are more distinct than the third, form almost a straight line and each is about three-fourths the length of the radius; the third laesura is perpendicular or almost perpendicular to the other two and up to one-half their length. The exine is indistinctly scabrate to finely granulate. The spore wall is less than $1 \mu \mathrm{m}$ thick. Diameters of spores from USNM 13287 (40 specimens) range from 14 to $20 \mu \mathrm{m}$, with an average of $16 \mu \mathrm{m}$. Diameters of spores from C 10797 (40 specimens) range from 13 to $18 \mu \mathrm{m}$, with an average of $15 \mu \mathrm{m}$. Except for a slight difference in size, the only other difference between the spores of the two species is that the grana on specimen USNM 13287 are more closely spaced. 


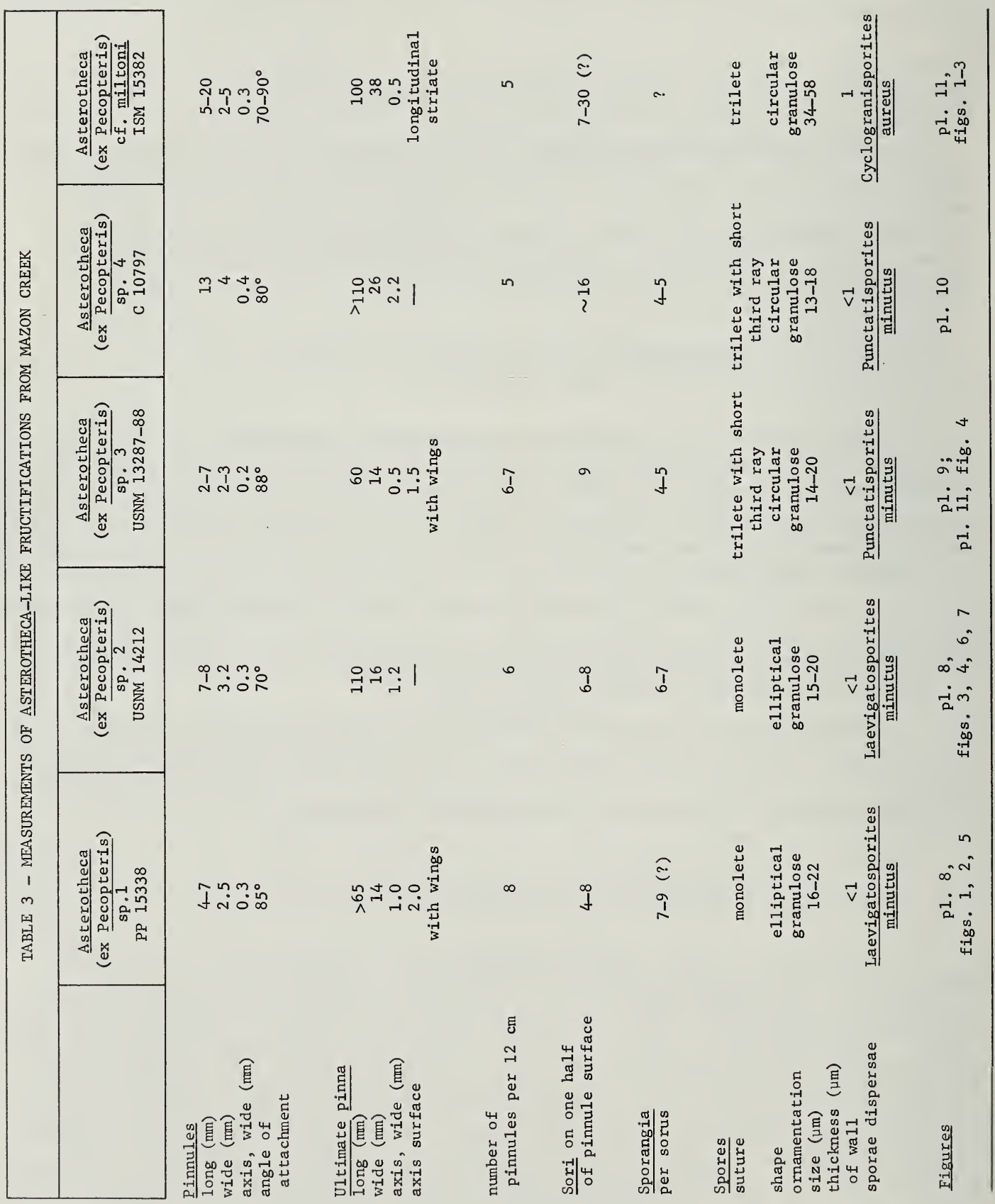


Comparison. - These spores as sporae dispersae are most similar to Punctatisporites minutus (Kosanke) Peppers, 1964. Kosanke (1950, p. 15-16) described this species from the Mattoon Formation (upper Pennsylvanian) of Illinois and gave a size range of 27.3 to $32.5 \mu \mathrm{m}$. Peppers (1964 and 1970) included within the taxon spores having the same morphology but as small as $15 \mu \mathrm{m}$. From more recently obtained data (Peppers, work in progress) from coals of the Mattoon Formation, it is thought that two rather distinct size ranges are represented: one spore has a size range of about 25 to $33 \mu \mathrm{m}$ as originally given by Kosanke, and the other has a size range of about 15 to $25 \mu \mathrm{m}$. Although spores of both size ranges usually occur together in the Mattoon Formation, the spores of the larger size range become dominant at about the middle of the Mattoon Formation. The holotype of Punctatisporites minutus came from these strata. The size difference is apparently useful in age determination and correlation of strata in the Illinois Basin. $\underline{P}$. minutus (small and large) occurs throughout the Pennsylvanian in the Illinois Basin. It is uncommon from the base of the Pennsylvanian through the Spoon Formation, common in the Carbondale, Modesto, and Bond Formations, and very abundant in the Mattoon Formation. This species corresponds to the species cf. Fabasporites Sullivan, 1964, of Clendening (1967), except that Fabasporites is described as being alete. Clendening stated that Fabasporites is very abundant in the Monongahela and Dunkard strata of the Appalachian Basin. It is of interest to note that this increase in abundance of these spore taxa toward the top of the Pennsylvanian corresponds to an increase in distribution of the form-genus Pecopteris.

\section{Asterotheca (ex Pecopteris) cf. miltoni pl. 11 , figs. $1-3$}

Description. - Specimen ISM 15382 most probably belongs to the species Asterotheca (ex Pecopteris) cf. miltoni. The preservation is relatively poor and the sporangia are filled mainly with mineral matter.

The spores are radially symmetrical, trilete, and circular to subcircular in equatorial view, and secondary folding is common. Laesurae are often obscured and are about two-thirds the length of the spore radius. Labra are 1 to $2 \mu \mathrm{m}$ wide. The exine is covered with grana that are circular to subcircular in plan view. They are about $1 \mu \mathrm{m}$ in diameter and usually wider than high. About one-half the spore surface area is occupied by grana. Some grana touch at their bases or are joined, and 65 to 80 grana extend beyond the spore margin. The exine is about $1 \mu \mathrm{m}$ thick. The diameters (35 specimens) range from 37 to $58 \mu \mathrm{m}$, with an average of $49 \mu \mathrm{m}$.

Comparison. - If found isolated, this spore would be assigned to Cyclogranisporites. It is similar to Cyclogranisporites cf. minutus Bharadwaj, 1957 as illustrated in Smith and Butterworth, 1967. These spores are very similar to those described from Asterotheca (ex Pecopteris) miltoni by Potonié (1962) and Laveine (1970).

\section{Discussion}

The sporangia are preserved in more or less three-dimensional form and filled with brown masses of spores and with white mineral matter. The cell wall has been destroyed and a cell pattern is not visible. In this type of preservation it is impossible to see any difference between Asterotheca, Acitheca, Scolecop- 
teris, Ptychocarpus and Cyathotracus. The generic determination can therefore be reached only through the specific determination. This can be a quite misleading way, especially if the veins and the outline of the lamina are as indistinct as in these fertile specimens.

The difficulty in distinguishing among some of the above genera has led to an extended discussion in the literature. Hirmer (1927) and Barthel (1970) considered Asterotheca synonymous with Scolecopteris. Mamay (1950) pointed out the discrepancy between the occurrences of the two genera: Scolecopteris is found mainly in coal balls and Asterotheca only as compressions. A similar discrepancy exists between Cyathotrachus (only in coal balls) and Ptychocarpus (mainly as compressions), which may be congeneric.

Spores in situ of approximately 70 species of Marattiaceae fructifications have been described in the literature (Watson, 1906; Scott, 1932; Andrews, 1943; Moore, 1946; Mamay, 1950; Remy and Remy, 1955, 1957; Doubinger, 1961; Ewart, 1961 ; Potonié, 1962, 1965, 1967; Brush and Barghoorn, 1964; Barthel, 1967;

Laveine, 1969, 1970). The spores vary from monolete to trilete with a short third ray to trilete; from laevigate to granulose to verrucose with irregular thickening of the exine (as in Torispora); and from about $10 \mu \mathrm{m}$ to at least $124 \mu \mathrm{m}$ in diameter. A discussion of each of these taxa is beyond the scope of this paper. Recently Laveine (1970, p. 288-296) has discussed the paleobotanical implications of using spore morphology in an attempt to verify natural relationships among species of the form-genus Pecopteris. Table 4 shows that there is no direct correlation between the form of the spores and several genera (Asterotheca, Scolecopteris, Ptychocarpus). Generalizations are possible for Danaeites (monolete, granulate, Laveine, 1970), Acitheca (only trilete; granulate or verrucose), Eoangiopteris (trilete, reticulate) and Cyathotrachus (monolete, laevigate). The lack of correlation in the larger genera may be natural, but it is also possible that this points out our lack of understanding of natural relationship in those groups.

The specimens studied here can be placed into three distinct groups according to the spores. Spores:

(1) monolete, bean-shaped, granulose, small (about $10 \times 20 \mu \mathrm{m}$ );

(2) trilete with one short ray, round, granulose, small (about $18 \mu \mathrm{m}$ );

(3) trilete, round, granulose, large (about $50 \mu \mathrm{m}$ ).

TABLE 4 - DISTRIBUTION OF FORMS OF SPORES OF CARBONIFEROUS MARATTIACEAE (FROM VARIOUS SOURCES CITED IN TEXT). A = ASTEROTHECA, AC = ACITHECA, $\mathrm{C}=$ CYATHOTRACHUS, $\mathrm{D}=$ DANAEITES, $\mathrm{E}=$ EOANGIOPTERIS, $\mathrm{P}=$ PTYCHOCARPUS, $\mathrm{S}=$ SCOLECOPTERIS

\begin{tabular}{|l|c|c|c|c|}
\hline & \multicolumn{2}{|c|}{ Trilete } & \multicolumn{2}{c|}{ Monolete } \\
\cline { 2 - 5 } & $\begin{array}{c}\text { number } \\
\text { of } \\
\text { species }\end{array}$ & genera & $\begin{array}{c}\text { number } \\
\text { of } \\
\text { species }\end{array}$ & genera \\
\hline smooth or punctate & 10 & $\mathrm{~S}+\mathrm{A}+\mathrm{P}$ & 19 & $\mathrm{~A}+\mathrm{S}+\mathrm{C}+\mathrm{P}$ \\
granulate & 12 & $\mathrm{~A}+\mathrm{Ac}$ & 18 & $\mathrm{~A}+\mathrm{D}+\mathrm{P}$ \\
verrucose & 1 & $\mathrm{Ac}$ & 1 & $\mathrm{~S}$ \\
reticulate & 3 & $\mathrm{E}+\mathrm{S}$ & - & $\mathrm{A}$ \\
conate & - & - & 2 & $\mathrm{~A}$ \\
cristate & - & - & 1 & \\
\hline
\end{tabular}


Two specimens from Mazon Creek, Illinois, tentatively assigned to Scolecopteris, were examined and spores were extracted. In both specimens the entire lamina of each pinnule appeared to be covered with spores. Macroscopically the two specimens appear to be similar. The specimens used are:

Scolecopteris sp. 1 C 10800
? Scolecopteris sp. 2 C 10803

Macroscopic Description. - Pinnules are tongue-shaped and Pecopterislike. They taper slightly towards the top and near the base. The midvein is thick and lateral veins are simple or forked once (text fig. 7). Subsidiary veins are probably present. Sterile pinnules are $5 \mathrm{~mm}$ long and $3 \mathrm{~mm}$ wide, and the midvein (visible only in specimen C 10803) is $0.3 \mathrm{~mm}$ wide. Fertile pinnules are 5 to 9 $\mathrm{mm}$ long and 3 to $3.5 \mathrm{~mm}$ wide. Pinnules touch each other at the margin and are attached to the pinna axis at an angle of $70^{\circ}-90^{\circ}$. The margin of fertile pinnules is strongly curved abaxially.

The pinna is about $6.5 \mathrm{~cm}$ long, $17 \mathrm{~mm}$ wide in the middle, and $12 \mathrm{~mm}$ wide at the base, and bears about 22 pinnules on each side. The pinna axis is $1.8 \mathrm{~mm}$ wide and has a weak and irregular longitudinal striation and stout hairs which are $0.2 \mathrm{~mm}$ thick at their bases (text fig. 8). Fructifications cover the entire under-surface of fertile pinnules. Each fructification is $1.4 \mathrm{~mm}$ long and 0.4 $\mathrm{mm}$ broad, extends nearly to the margin of the pinnule, and has a longitudinal striation vertically oriented to the midvein. Single sporangia are not discernible in the two specimens.

\section{? Scolecopteris sp. 1 pl. 12 , figs. $3,4,5,6$}

Description.- The spores (specimen C 10800) are trilete and circular to subcircular in transverse plane. Laesurae are distinct and straight, and two of the laesurae generally form almost a straight line and are about equal in length to the spore radius; the third laesura is perpendicular or almost perpendicular to the other two and up to one-half their length; minor folds are usually present along the two longest rays. The spore exine is laevigate and 1 to $1.5 \mu \mathrm{m}$ thick. The spore diameters (40 specimens) range from 16 to $23 \mu \mathrm{m}$, with an average of $19 \mu \mathrm{m}$.

Comparison. - If found dispersed, the spores of C 10800 would be classified as Punctatisporites; however, no dispersed species of Punctatisporites that could be correlated with these spores were noted, and spores similar to those of $\mathrm{C} 10800$ have not been recognized in macerated rocks from the Illinois Basin.

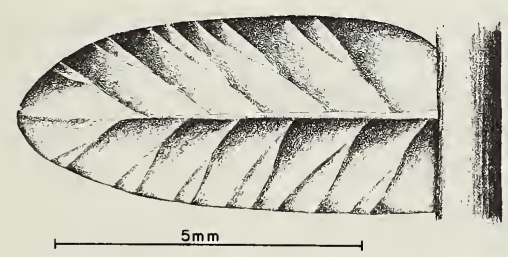

Text fig. 7 - Sterile pinnule of ? $\underline{\text { Scole- }}$ copteris spec. 2 .

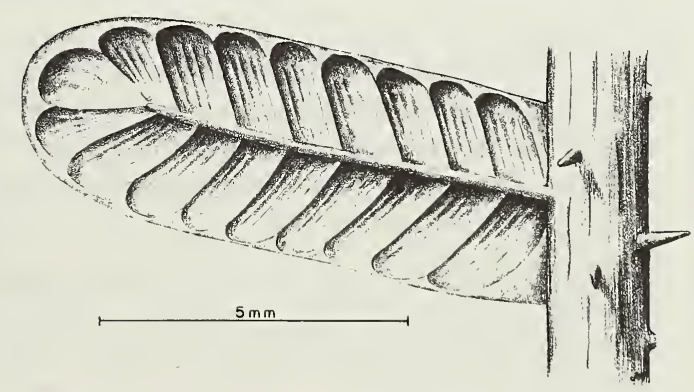

Text. fig. 8 - Fertile pinnule of ? Scolecopteris spec. 2 . 
Latosporites minutus Bharadwaj, 1957, and Laevigatosporites perminutus Alpern, 1959, are monolete, circular, and more or less smooth, but they are thinner and more often folded than the spores of C 10800 .

\section{? Scolecopteris sp. 2}

pl. 12, figs. $1,2,7-10$

Description. - The spores of specimen C 10803 are trilete and circular to elliptical in transverse plane. Two long laesurae extend about three-fourths the spore radius, but the third laesura is less than one-half the length of the other two. The spore surface is covered with minute papillae and spines that are so closely spaced that parts of the spore surface appear punctate. Sculptural elements are less than $0.5 \mu \mathrm{m}$ in diameter and are about twice as long as they are wide. The exine is 1 to $2.5 \mu \mathrm{m}$ thick. Diameter size range (30 specimens) is from 18 to $24 \mu \mathrm{m}$, with an average of $20 \mu \mathrm{m}$. Because of the close spacing of the minute spines, the true nature of the ornamentation is best shown by scanning electron microscopy. Under transmitted light, the exine appears punctate, granulose, or papillate.

Comparison. - The spores from fructification C 10803 are in the size range of Laevigatosporites globosus and are therefore correlated with that species. The surface ornamentation of these spores is similar also to that of Punctatisporites obliquus Kosanke, 1950, and $\underline{P}$. orbicularis Kosanke, 1950. Habib (1966) and Peppers (1970) noted that $\underline{\underline{L}}$. globosus is similar to $\underline{\mathrm{P}}$. obliquus except that it is smaller, has a shorter third ray, and is more ellipsoidal than $\underline{P}$. obliquus. The spores of specimen C 10803 are apparently more circular than typical specimens of Laevigatosporites globosus, but this difference is probably the result of differences in preservation. It is conceivable that they represent immature specimens of Punctatisporites obliquus, but the minimum size range of the latter is about $7 \mu \mathrm{m}$ greater than the maximum size of the spores in specimen C 10803. The ornamentation of the spores in situ is well developed for immature spores.

Potonié and Kremp (1954) placed Laevigatosporites globosus in the genus Latosporites Potonié and Kremp, 1954, which is reserved for monolete spores having laevigate to infrareticulate exines. Examination of specimens of Laevigatosporites globosus under oil immersion objective reveals that the ornamentation is minutely papillate to spinose but that it appears to be punctate or infrapunctate where the projections are closely packed. L. globosus is a species that is commonly present in the Illinois Basin from the top of the Abbott Formation to the lower part of the Mattoon Formation.

\section{Discussion}

The two fertile compressions resemble very much the genus Danaeites. The longitudinal striation of each fructification, however, and the missing subdivisions of the spore masses exclude the genus Danaeites. The specimens resemble more closely some species of Scolecopteris in which the sori are inclined towards the midvein (text fig. 9). This inclined position has been reported in

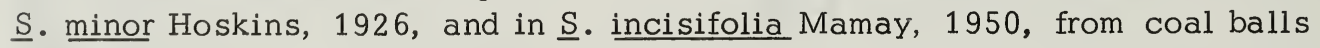
(Graham, 1934; Mamay, 1950). None of these species can be directly compared with the specimens described here, because of differences in the size of pinnules and fructifications. Our specimens correspond in size, however, with $\underline{S}$. oliveri 


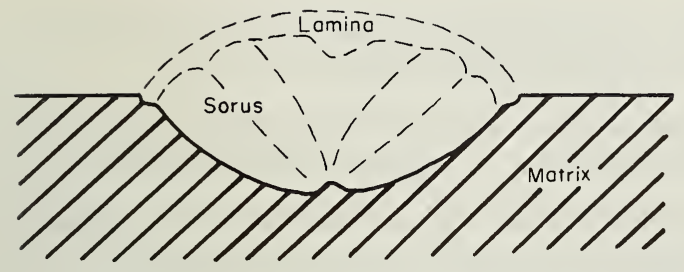

Text fig. 9 - Cross section of ? Scolecopteris $\mathrm{sp}$. with interpretation of fertile structure.

(Scott, 1932), described from the Permo-Carboniferous of Autun, France. As the mode of preservation is different (petrifaction versus compression) and the number of our specimens small, further comparison cannot be made. Jongmans and Gothan (1925) described a compression species, Scolecopteris (ex Pecopteris) verbeeki Gothan and Jongmans, 1925, from the Stephanian of Sumatra. It has smaller pinnules than the forms considered here, but has a somewhat similar aspect in preservation (Jongmans and Gothan, 1925, pl. 3, figs. 1a, 2a).

The two specimens described here contain different spore genera but, with the lack of soral and sporangial data, the establishment of two new species is not warranted at this time. Therefore, they are designated ? Scolecopteris sp. 1 (C 10800) and ? S. sp. 2 (C 10803). The designation to the genus Scolecopteris is only tentative, because the structure of the base of the sorus cannot be determined from the compression.

Spores from several other species of Scolecopteris have been described and are reviewed here for comparison. Scott (in Potonié, 1962, p. 98-99) described the spores of Scolecopteris oliveri Scott, 1932, as monolete, oval, rugose or tuberculate, and about $18 \mu \mathrm{m}$ in diameter. The spores of $\underline{S}$. elegans Zenker, 1837, were considered trilete, circular, and finely punctate by Strasburger, 1874 (in Potonié, 1962), but Mamay (1950) concluded that the spores of this species are smooth. Mamay also listed two species (S. latifolia Graham,

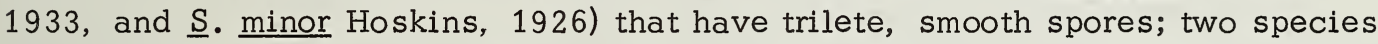

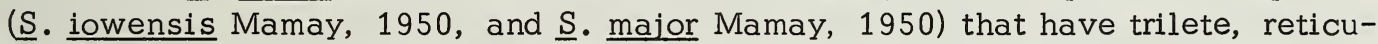
late spores; and one species ( . incisifolia Mamay, 1950) with bilateral smooth spores. Ewart (1961) found monolete smooth spores, about $12 \mu \mathrm{m}$ long, in the

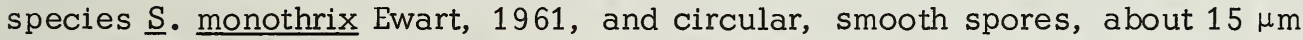
in diameter, with "a crescent-shaped indentation" in $\underline{S}$. illinoensis Ewart, 1961 . Scolecopteris radforthii Andrews, 1943, contains trilete, laevigate spores which were considered immature. According to Potonié $(1965, p .44)$ the spores of $\underline{S}$. polymorpha (Brongniart, 1828) Stur, 1883, are also immature, trilete, subtriangular, and laevigate.

\section{REFERENCES}

Abbott, M. L., 1954, Revision of the Paleozoic fern genus Oligocarpia: Palaeontographica B, v. 96, p. 39-65.

Alpern, B., 1959, Contribution à l'étude palynologique et petrographique des charbons français: $\mathrm{Ph} . \mathrm{D}$. thesis, l' Université de Paris, privately published, $314 \mathrm{p}$.

Andrews, H. N., 1943, Contributions to our knowledge of American Carboniferous floras. VI. Certain filicinean fructifications: Ann. Missouri Bot. Garden, v. 30, p. 429-442. 
Andrews, H. N., and S. H. Mamay, 1948, A Crossotheca from northern Illinois: Ann. Missouri Bot. Garden, v. 35, no. 3, p. 203-206.

Arnold, C. A., 1938, Note on a lepidophyte strobilus containing large spores from Braidwood, Illinois: Am. Midland Nat., v. 20, no. 3, p. 709-712.

Bailey, W. H., 1860, On Corynepteris, a new generic form of fossil fern; with observations on the associate plants from the coal-measures of Glin, County of Limerick: Geol. Soc. Dublin Jour., v. 8, (3), p. 237-24l.

Balme, B. E., 1957, Spores and pollen grains from the Mesozoic of Western Australia: C.S.I.R.O. Aust., Coal Res. Sect., T. C., 25, p. 1-48.

Barthel, M., 1967, Sporen in situ aus dem Erzgebirgischen und Döhlener Becken: Monatsberichte Deutsch. Akad. Wissensch. Berlin, v. 9, no. h 4/5, p. 345-352.

Barthel, M., 1970, Alte und neue wertvolle Funde fossiler Pflanzen aus dem Rotliegenden: Wiss. Zeitschr. Humboldt-Univ. Berlin, Math.-Nat. Reihe, v. 19, (2/3), p. 268-274.

Bhardwaj, D. C., 1957, The palynological investigations of the Saar coals (Part 1-Morphography of sporae dispersae): Palaeontographica, Abt. B, v. 101, p. 73-125.

Bode, H., 1958, Die floristische Gliederung des Oberkarbons der Vereinigten Staaten von Nordamerika: Z. deutsch. geol. Ges., V. 110, p. 217-259.

Bode, H., 1960, Die floristischen Verhältnisse an der Westfal/Stefan - Grenze im Europäischen und U.S. - Amerikanischen Karbon: C. R. IV, Congr. Stratigr. Geol. Carbonif. Heerlen, 1958, v. 1, p. 49-58.

Brush, G. S., and E. S. Barghoorn, 1964, The natural relationships of some Carboniferous microspores: Jour. Paleont., V. 38, p. 325-330.

Brush, G. S., and E. S. Barghoorn, 1965, On "The natural relationships of some Carboniferous microspores": A reply: Jour. Paleont., v. 39, p. 732-733.

Butterworth, M. A., and R. W. Williams, 1958, The small spore floras of coals in the Limestone Coal Group and Upper Limestone Group of the Lower Carboniferous of Scotland: Royal Soc. Edinburgh Trans., v. 63, pt. 2, no. 17, p. 353-392.

Chaloner, W. G., 1956, On Sporangiostrobus langfordi sp. nov., a new fossil lycopod cone from Illinois: Am. Midland Nat., v. 55, p. 437-442.

Clendening, J. A., 1967, Three new species of Fabasporites Sullivan, 1967, from the Appalachian Basin: Proc. West Virginia Acad. Sci., v. 39, p. 315-319.

Daber, R., 1955, Pflanzengeographische Besonderheiten der Karbonflora des Zwickau-Lugauer Steinkohlenreviers: Geologie, Beih. no. 13., 95 p.

Danzé, J., 1956, Les fougères Sphénoptéridiennes du bassin houiller du Nord de la France: Et. Géol. Atlas Top. sout. Serv. Géol., H. B. N. P. C., $568 \mathrm{p}$.

Darrah, W. C., 1936, A new Macrostachya from the Carboniferous of Illinois: Harvard Univ. Bot. Mus. Leaflet, v. 4, no. 4, p. 52-63. 
Darrah, W. C., 1937, Codonotheca and Crossotheca; polleniferous structures of pteridosperms: Harvard Univ. Bot. Mus. Leaflet, v. 4, no. 9, p. 153-172.

Darrah, W. C., 1938, A new gleicheniaceous fern from Illinois: Harvard Univ. Bot. Mus. Leaflet, v. 5, no. 8, p. 145-159.

Darrah, W. C., 1970, A critical review of the Upper Pennsylvanian floras of the eastern United States with notes on the Mazon Creek Flora of Illinois: W. C. Darrah, Gettysburg (1969), 220 p.

Delevoryas, T., 1964, A probable pteridosperm microsporangiate fructification from the Pennsylvanian of Illinois: Palaeontology, v. 7, p. 60-63.

Doubinger, J., 1961, Spores de quelques fructifications fossiles du Stéphanien et de l' Autunien: Pollen et Spores, v. 3, p. 353-372.

Doubinger, J., and R. Rauscher, 1966, Spores du Viséan marin de Bourbach-LeHaut dans les Vosges du Sud: Pollen et Spores, v. 8, no. 2, p. 361-405.

Eggert, D. A., and T. N. Taylor, 1966, Studies of Paleozoic ferns: On the genus Tedelea gen. nov.: Palaeontographica B, v. 118, p. 52-73.

Ewart, R. B., 1961, Two new members of the genus Scolecopteris: Ann. Missouri Bot. Garden, v. 48, p. 275-289.

Graham, R., 1934, Pennsylvanian flora of Illinois as revealed in coal balls. I: Bot. Gaz., v. 95, p. 453-476.

Habib, Daniel, 1966, Distribution of spore and pollen assemblages in the Lower Kittanning Coal of western Pennsylvania: Palaeontology, v. 9, pt. 4, p. 629-666.

Hirmer, M., 1927, Handbuch der Paläobotanik, Vol. I: Oldenbourg, Munich and Berlin, $624 \mathrm{p}$.

Hoskins, J. H., 1926, Structure of Pennsylvanian plants from Illinois: Bot. Gaz., v. 82, p. 427-436.

Ibrahim, A. C., 1933, Sporenformen des Aegirhorizonts des Ruhr-Reviers: Konrad Triltsch, Wuerzburg, $47 \mathrm{p}$.

Jongmans, W. J., and W. Gothan, 1925, Beiträge zur Kenntnis der Flora des Oberkarbons von Sumatra: Verh. Geol.-Miinbouwkundig Genootschap Nederland Kolonien., Geol. Ser., v. 8, p. 279-304.

Jongmans, W. J., and W. Gothan, 1934, Florenfolge und vergleichende Stratigraphie des Karbons der östlichen Staaten Nord-Amerika's. Vergleich mit West-Europa: Geologisch Bureau Heerlen, Jaarverslag 1933, p. 17-44.

Jongmans, W. J., 1937, Contribution to a comparison between the Carboniferous floras of the United States and Western Europe: C. R. II, Congr. Stratigr. Carbonif. Heerlen, 1935, v. 1, p. 363-387.

Jongmans, W., 1957, Fossilium Catalogus, II: Plantae, pars 31, p. 179-246.

Jongmans, W., and S. J. Dijkstra, 1958, Fossilium Catalogus, II: Plantae, pars 33 , p. 367-462.

Kidston, R., 1887, On the fossil flora of the Radstock Series of the Somerset and Bristol coal field (Upper Coal Measure): Trans. Roy. Soc. Edinburgh, v. 33, p. 335-417. 
Kidston, R., 1923, Fossil plants of the Carboniferous rocks of Great Britain: Mem. Geol. Surv. Great Britain, Paleont., v. 2, pt. 4, p. 275-376.

Knopp, G., 1933, Paläobotanische Studien über das Albert - und das Augustensfreudeflöz der Lazisker Schichten (Westfal B) in polnisch Oberschlesien: Arbeiten Inst. Paläobotanik Petrogr. Brennsteine, v. 3, p. 152-193.

Kosanke, R. M., 1950, Pennsylvanian spores of Illinois and their use in correlation: Illinois Geol. Survey Bull. 74, 128 p.

Kosanke, R. M., 1955, Mazostachys - A new calamite fructification: Illinois Geol. Survey Rept. Inv. 180, 37 p.

Langford, G., 1958, The Wilmington coal flora from a Pennsylvanian deposit in Will County, Illinois: Esconi Associates, Downers Grove, Illinois, 360 p.

Langford, G., 1963, The Wilmington coal fauna and additions to the Wilmington coal flora from a Pennsylvanian deposit in Will County, Illinois: Esconi Associates, Downers Grove, Illinois, $280 \mathrm{p}$.

Laveine, J. P., 1969, Quelques pécoptéridinées houillères à la lumière de la palynologie: Pollen et Spores, v. 11, p. 619-668.

Laveine, J. P., 1970, Quelques pécoptéridinées houillères à la lumière de la palynologie (II). Implications paléobotaniques et stratigraphiques: Pollen et Spores, V. 12, p. 235-297.

Lesquereux, L., 1866, Report on the fossil plants of Illinois, in A. H. Worthen, Palaeontology: Geol. Sur. of Ill., v. 2, p. 425-667.

Lesquereux, L., 1870, Report on the fossil plants of Illinois, in A. H. Worthen, Geology and palaeontology: Geol. Surv. of Ill., v. 4, p. 375-508.

Lesquereux, L., 1879, 1880, 1884, Description of the coal flora of the Carboniferous formation in Pennsylvania and throughout the United States: Second

Geol. Surv. Pennsylvania, Report of Progress P: Atlas, 1879; v. 1 and 2, p. 1-694, 1880; v. 3, p. 695-977, 1884.

Mamay, S. H., 1950, Some American Carboniferous fern fructifications: Ann. Missouri Bot. Garden, v. 37, p. 409-459.

Menerdez, C. A., and C. L. Azcuy, 1969, Microflora Carbonica de la Localidad de Paganzo, Parte I: De Ameghiniana, v. 6, no. 2, p. 77-97.

Moore, L. R., 1946, On the spores of some Carboniferous plants; their development: Geol. Soc. London, Quart. Jour., v. 102, pt. 3, p. 251-298.

Moore, L. R., 1965, Concerning "The natural relationships of some Carboniferous microspores" by Brush and Barghoorn: Jour. Paleont., v. 39, p. 296-297.

Nemejc, F., 1938, A revision of the Carboniferous and Permian floras of the coal districts of central Bohemia (part 2. Sphenopterides: A. Coenopteridae): Palaeontographica Bohemiae, no. 16, p. 33-56.

Noé, A. C., 1925, Pennsylvanian flora of northern Illinois: Illinois Geol. Survey Bull. 52, $113 \mathrm{p}$.

Noé, A. C., 1930, Correlation of Illinois coal seams with European horizons: Illinois Acad. Sci. Trans., 1929, v. 22, p. 470-472. 
Noé, A. C., 1936, Some recent attempts to correlate the later Paleozoic of America and Europe: Illinois Acad. Sci. Trans., 1935, v. 28, p. 171-172.

Peppers, R. A., 1964, Spores in strata of Late Pennsylvanian cyclothems in the Illinois Basin: Illinois Geol. Survey Bull. 90, 89 p.

Peppers, R. A., 1970, Correlation and palynology of coals in the Carbondale and Spoon Formations (Pennsylvanian) of the northeastern part of the Illinois Basin: Illinois Geol. Survey Bull. 93, 173 p.

Peppers, R. A., and Pfefferkorn, H. W., 1970, A comparison of the floras of the Colchester (No. 2) Coal and Francis Creek Shale, in W. H. Smith et al., Depositional environments in parts of the Carbondale Formation - western and northern Illinois: Illinois Geol. Survey, Guidebook Series No. 8, p. 6l-74.

Pfefferkorn, G. E., 1969, Preparation methods and artifacts in scanning electron microscopy: Proc. Stereoscan - Colloquium II, Chicago, 1969, p. 81-87.

Pfefferkorn, G. E., 1970, Specimen preparation techniques: Proc. 3rd Scanning Electron Microsc. Symposium, Chicago, 1970, p. 89-96.

Pfefferkorn, H. W., (in press), Revision der Sphenopteriden Discopteris karwinensis Stur, Discopteris vuellersi Stur und der Gattung Discopteris Stur: Argumenta Palaeobotanica.

Phillips, T. L., and S. W. Rosso, 1970, Spores of Botryopteris globosa and Botryopteris americana from the Pennsylvanian: Am. Jour. Bot., v. 57 (5), p. 543-551.

Potonié, H., 1897, Lehrbuch der Pflanzenpaläontologie: pt. 1, 2: Berlin, p. 1208.

Potonié, H., 1900, Über die fossilen Filicales im Allgemeinen und die Reste derselben zweifelhafter Verwandtschaft. in Engler, A. and K. Prantl; Die natürlichen Pflanzenfamilien nebst ihren Gattungen und wichtigeren Arten insbesondere der Nutzpflanzen, Teil 1, Abt. 4, p. 473-519.

Potonié, R., and G. O. W. Kremp, 1954, Die Gattungen der paläozoischen Sporae dispersae und ihre Stratigraphie: Geol. Jahrb., v. 69, p. 111-199.

Potonié, R., and G. O. W. Kremp, 1955, Die Sporae dispersae des Ruhrkarbons, ihre Morphographie und Stratigraphie mit Ausblicken auf Arten anderer Gebiete und Zeitabschnitte, Teil I: Palaeontographica, Abt. B, v. 98, $136 \mathrm{p}$.

Potonié, R., 1962, Synopsis der Sporae in situ: Beih. Geol. Jahrb., no. 52, 204 p.

Potonié, R., 1965, Fossile Sporae in situ. Vergleich mit den Sporae dispersae. Nachtrag zur Synopsis der Sporae in situ: Forschnungsberichte Landes Nordrhein-Westfalen, no. 1483, 74 p.

Potonié, R., 1967, Versuch der Einordnung der fossilen Sporae dispersae in das phylogenetische System der Pflanzenfamilien: Forschungsberichte Landes Nordrhein-Westfalen, no. 1761,310 p.

Raabe, H., 1966, Zur deskriptiven Terminologie des fossilen Farnlaubes besonders bei Sphenopteris (I. Teil): N. Jb. Geol. Paläont. Mh., no. 3, p. 168-178. 
Read, C. B., and S. H. Mamay, 1964, Upper Paleozoic floral zones and floral provinces of the United States: U. S. G. S. Prof. Paper 454-K, 35 p.

Remy, W., 1954, Beiträge zur Kenntnis der Rotliegendflora Thüringens: Teil II: Fruktifikationen: Sitzungsber. deutsch. Akad. Wiss. Berlin, Klasse Math. Naturwiss., Jahrgang 1953, no. 3, 32 p.

Remy, R., and W. Remy, 1955, Mitteilungen über Sporen, die aus inkohlten Fruktifikationen von echten Farnen des Karbon gewonnen wurden.: Abh. deutsch. Akad. Wiss. Berlin, Klasse Chem. Geol. Biol., no.1, p. 47-48.

Remy, W., and R. Remy, 1957, Durch Mazeration fertiler Farne des Paläozoikums gewonnene Sporen: Paläont. Zeitschr., v. 31 (1/2), p. 55-65.

Remy, W., and R. Remy, 1968, Atlas wichtiger stratigraphischer Leit - und Charakterarten im euramerischen Florenbereich: Argumenta Palaeobotanica, v. 1 , p. 55-86.

Schopf, J. M., L. R. Wilson, and R. Bentall, 1944, An annotated synopsis of Paleozoic fossil spores and the definition of generic groups: Illinois Geol. Surv. Rept. Inv. 91, 73 p.

Schopf, J. M., 1948, Pteridosperm male fructifications - American species of Dolerotheca, with notes regarding certain allied forms: J. Paleont., v. 22, no. 6, p. 681-724.

Scott, D. H., 1932, On a $\underline{\text { Scolecopteris }}$ (S. oliveri, sp. n.) from the PermoCarboniferous of Autun. I. The fructification: Jour. Linn. Soc. London, v. $44, \mathrm{p}, 1-12$.

Sellards, E. H., 1902, On the fertile fronds of Crossotheca and Myriotheca, and on the spores of other Carboniferous ferns, from Mazon Creek, Illinois: Am. Jour. Sci., ser. 4, v. 14, no. 81, art. 22, p. 195-202.

Sellards, E. H., 1903, Codonotheca, a new type of spore-bearing organ from the coal measures: Am. Jour. Sci., ser. 4, v. 66, p. 87-95.

Smith, A. H. V., and M. A. Butterworth, 1967, Miospores in British coal seams: Palaeontological Assoc. London, Special Paper No. 1, 324 p.

Stur, D., 1883, Zur Morphologie und Systematik der Culm - und Carbonfarne: Sitsungsber. k. Akad. Wiss. Wien, v. 88, Abth. I.

Sullivan, H. J., 1964, Miospores from the Drybrook Sandstone and associated measures in the Forest of Dean basin, Gloucestershire: Palaeontology, v. 7, no. 3, p. 351-392.

Taylor, T. N., 1967, On the structure and phylogenetic relationships of the fern Radstockia Kidston: Palaeontology, v. 10, p. 43-46.

Taylor, T. N., and D. A. Eggert, 1969, Preliminary study of spores from Carboniferous fructifications utilizing the scanning electron microscope: Proc. Engis Stereoscan Coll. 1969, p. 97-107.

Taylor, T. N., and D. A. Eggert, 1969, Studies of spores from Carboniferous fructifications. I. Introduction and preliminary survey utilizing the scanning electron microscope: Trans. Amer. Microsc. Soc., v. 88, p. 431-444. 
Watson, D. M. S., 1906, On a "Fern" synangium from the Lower Coal Measures of Shore, Lancashire: Jour. Roy. Microsc. Soc., p. 1-3.

Zeiller, R., 1883, Fructifications de fougères du terrain houiller: Ann. Sci. Naturelles, Sixième Sér., Bot., v. 16, p. 177-207.

Zenker, J. C., 1837, Scolecopteris elegans Zenk. Ein neues fossiles Farrngewächs mit Fructificationen: Linnaea, v. 11, p. 509-512. 

PLATES

AND

EXPLANATIONS 
PLATE 1

Stellatheca latiloba Danzé, 1956, p. 5

Figure

1 Specimen USNM 13382; scale $1: 1$; under xylol.

2 Specimen USNM 13382; scale 5:1; under xylol.

3 Specimen USNM 14218; scale $1: 1$

4 Specimen USNM 14218; scale $5: 1$

5 Specimen USNM 14218; scale 5:1; under xylol. 

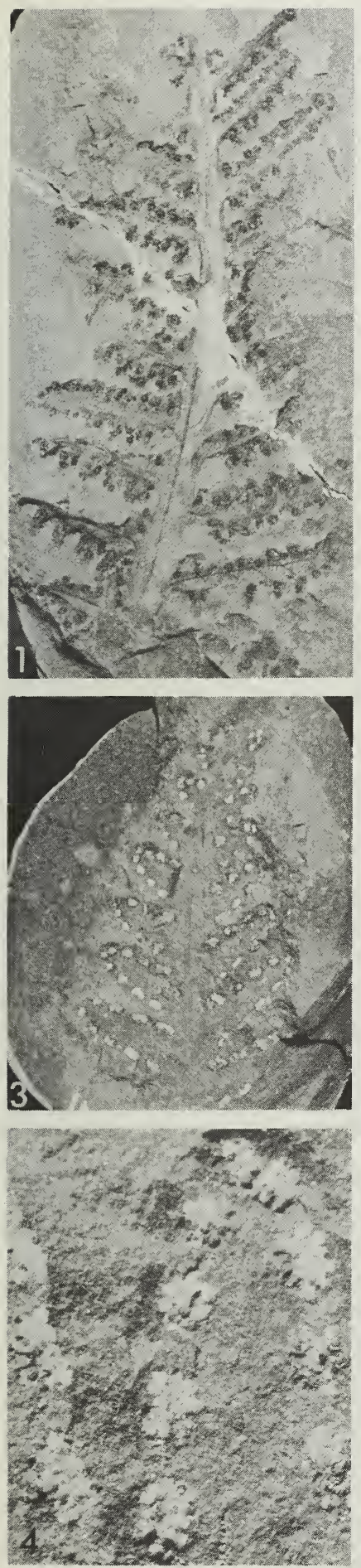

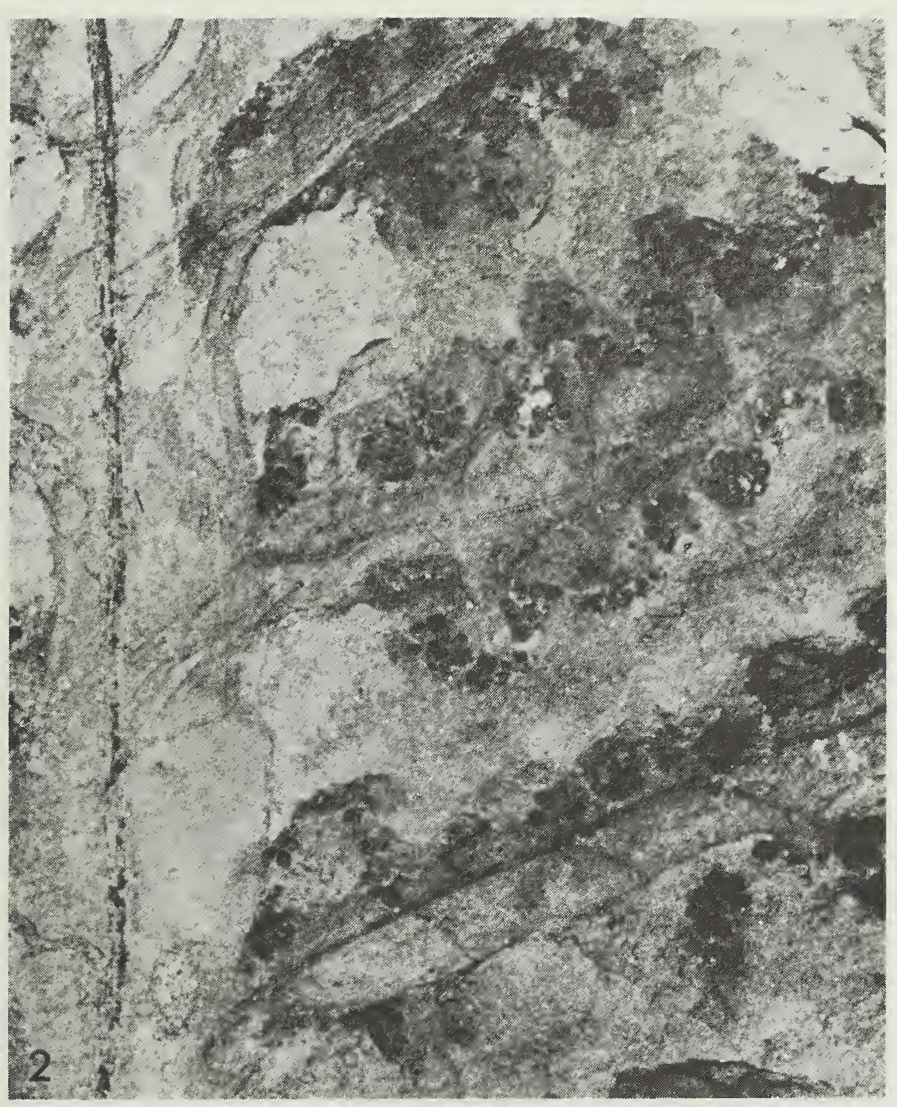

3.

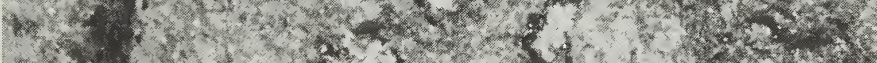

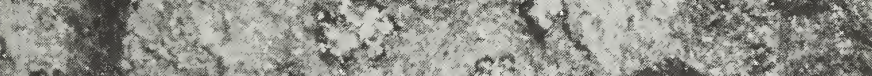

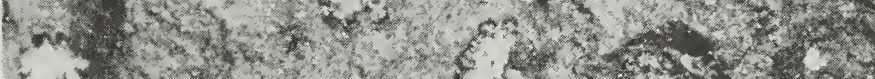

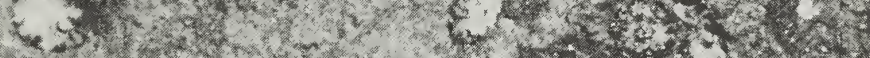

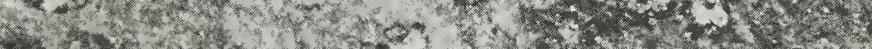

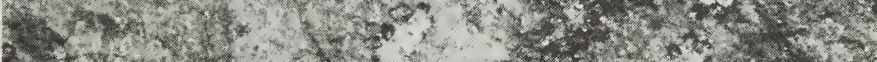

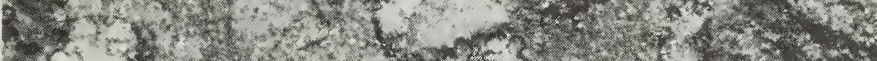

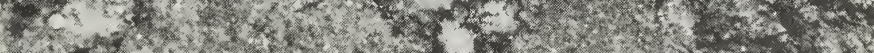

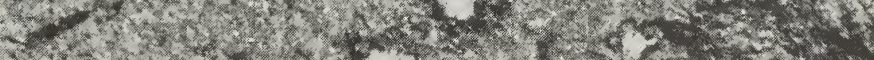

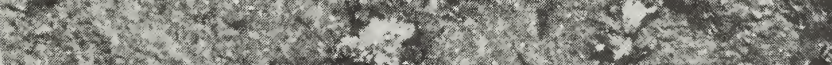

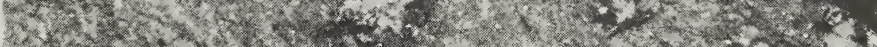

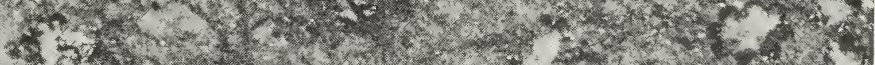

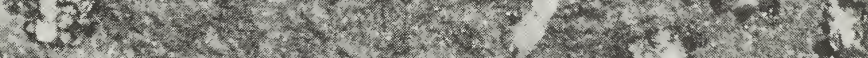
atrat

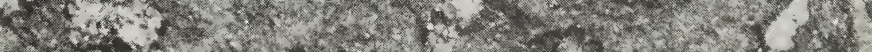

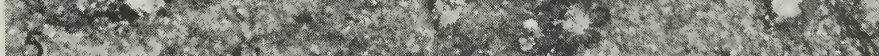


PLATE 2

Stellatheca latiloba Danzé, 1956, p. 5

Figure

1 Specimen USNM 13386; scale 1:1

2 Specimen USNM 13385 (counterpart of USNM 13386); scale 1:1

3 Specimen USNM 13386; scale $5: 1$

Spores of Stellatheca latiloba (correlated with ? Apiculatasporites, ? Microreticulatisporites, ? Foveosporites, ? Cyclogranisporites)

Figure

4-6 Specimen USNM 13386; scale 1200:1; scanning electron micrographs.

7 Specimen USNM 13386; negative 8704; coordinates $130.0 \times 50.5$; size $35.8 \times 30.9 \mu \mathrm{m}$; scale $1000: 1$ *

8 Specimen USNM 13385; negative 8573; coordinates $135.3 \times 48.0$; size $23.1 \times 21.8 \mu \mathrm{m}$; scale 1000:1. (Specimens USNM 13385 and 13386 are counterparts.)

9 Specimen USNM 13386; negative 8532; coordinates $137.5 \times 51.0$; size $32.8 \times 28.6 \mu \mathrm{m}$; scale $1000: 1$

10 Specimen USNM 13386; negative 8528; coordinates $130.5 \times 50.1$; size $35.8 \times 31.9 \mu \mathrm{m}$; scale $1000: 1$

* All coordinates refer to the mechanical stage of a Spencer microscope (serial number 417297) at the Illinois State Geological Survey. 

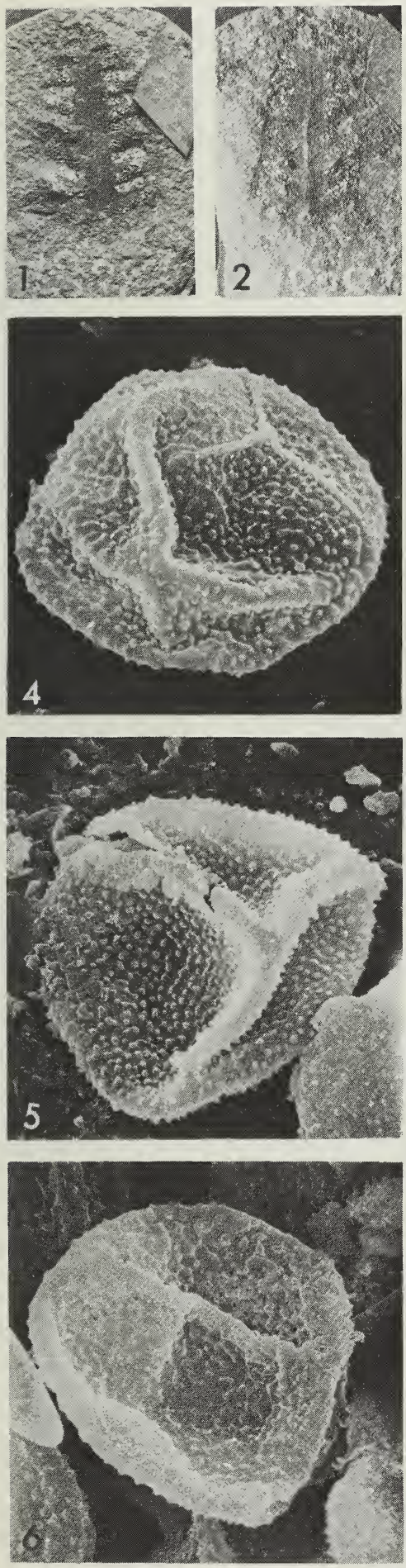
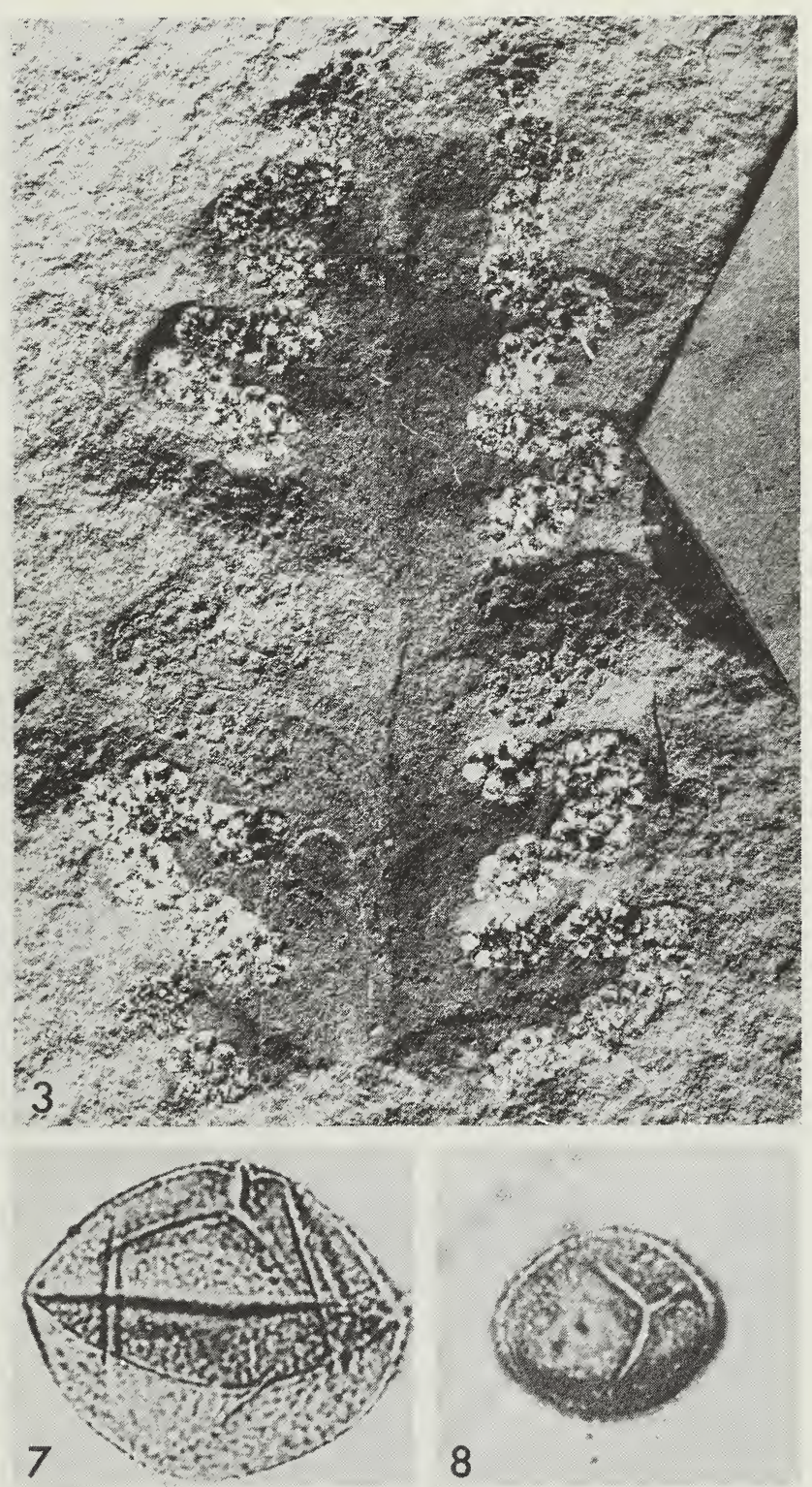

8
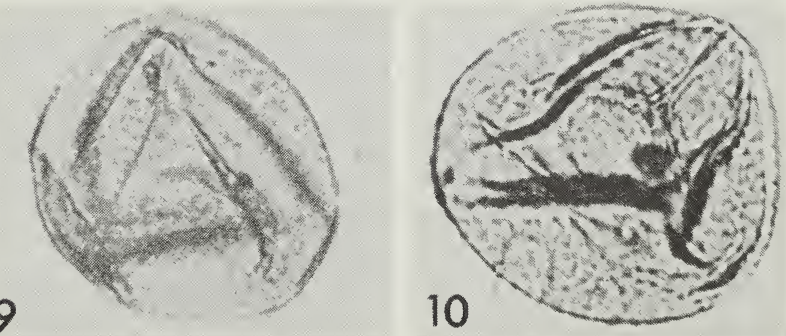


\section{PLATE 3}

Stellatheca latiloba Danzé, 1956, p. 5

\section{Figure}

1 Specimen USNM 13383; scale $1: 1$; under xylol.

2 Specimen USNM 13383; scale $5: 1$

3 Specimen USNM 13386; scale 20:1

4 Specimen USNM 13386; scale 5:1; under xylol.

Stellatheca ornata (Lesquereux, 1884) comb. nov., p. 8

Figure

5 Specimen ISM 15548b; scale 5:1; under xylol. 

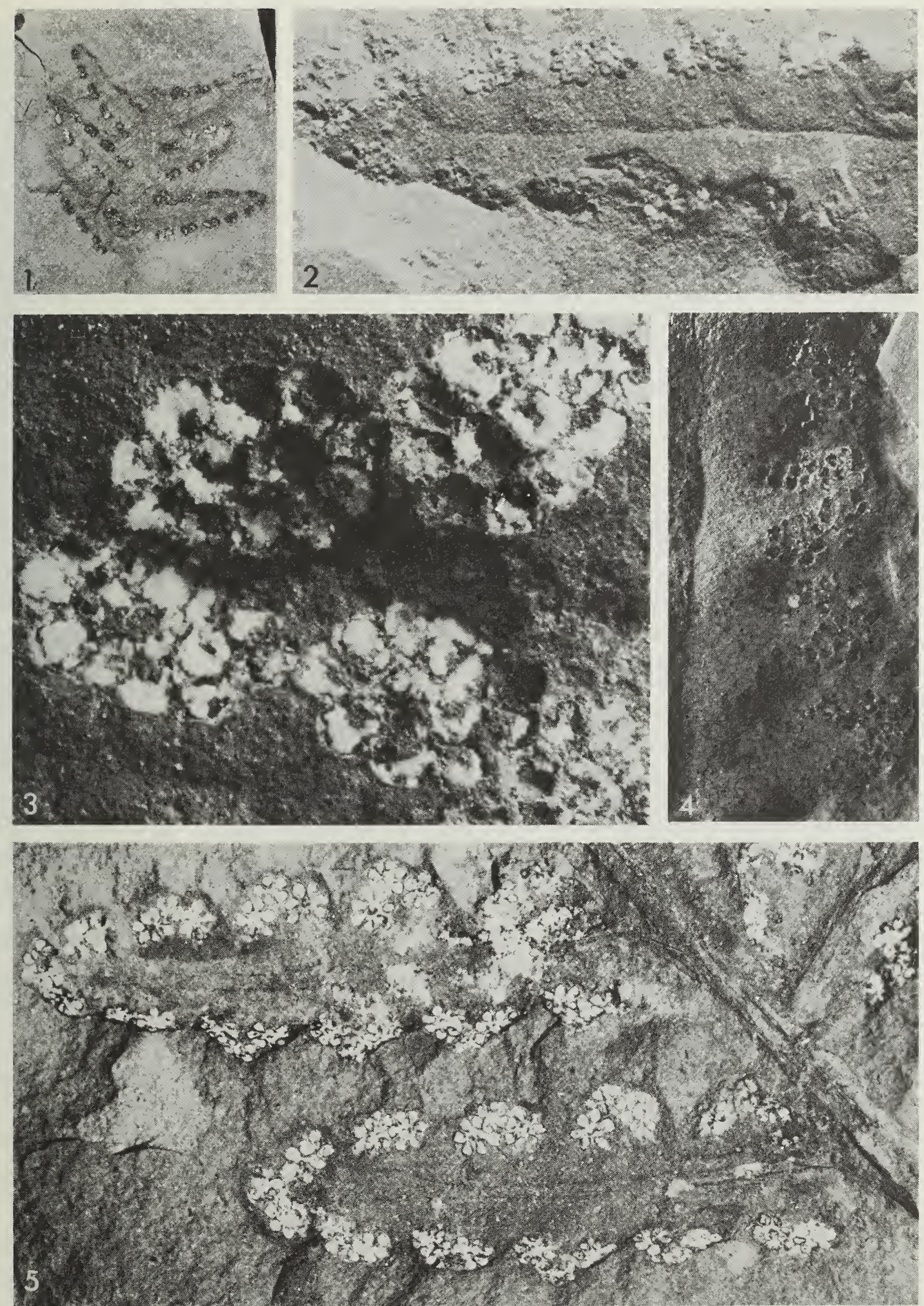
PLATE 4

Stellatheca ornata (Lesquereux, 1884) comb. nov., p. 8

\section{Figure}

1 Specimen ISM 15548; scale 1:1; under xylol.

2 Specimen USNM 13388; scale 5:1

3 Specimen USNM 13388; scale $1: 1$

4 Specimen ISM $15548 \mathrm{~b}$; scale $5: 1$

5 Specimen ISM 15548b; scale 8:1, under xylol. 

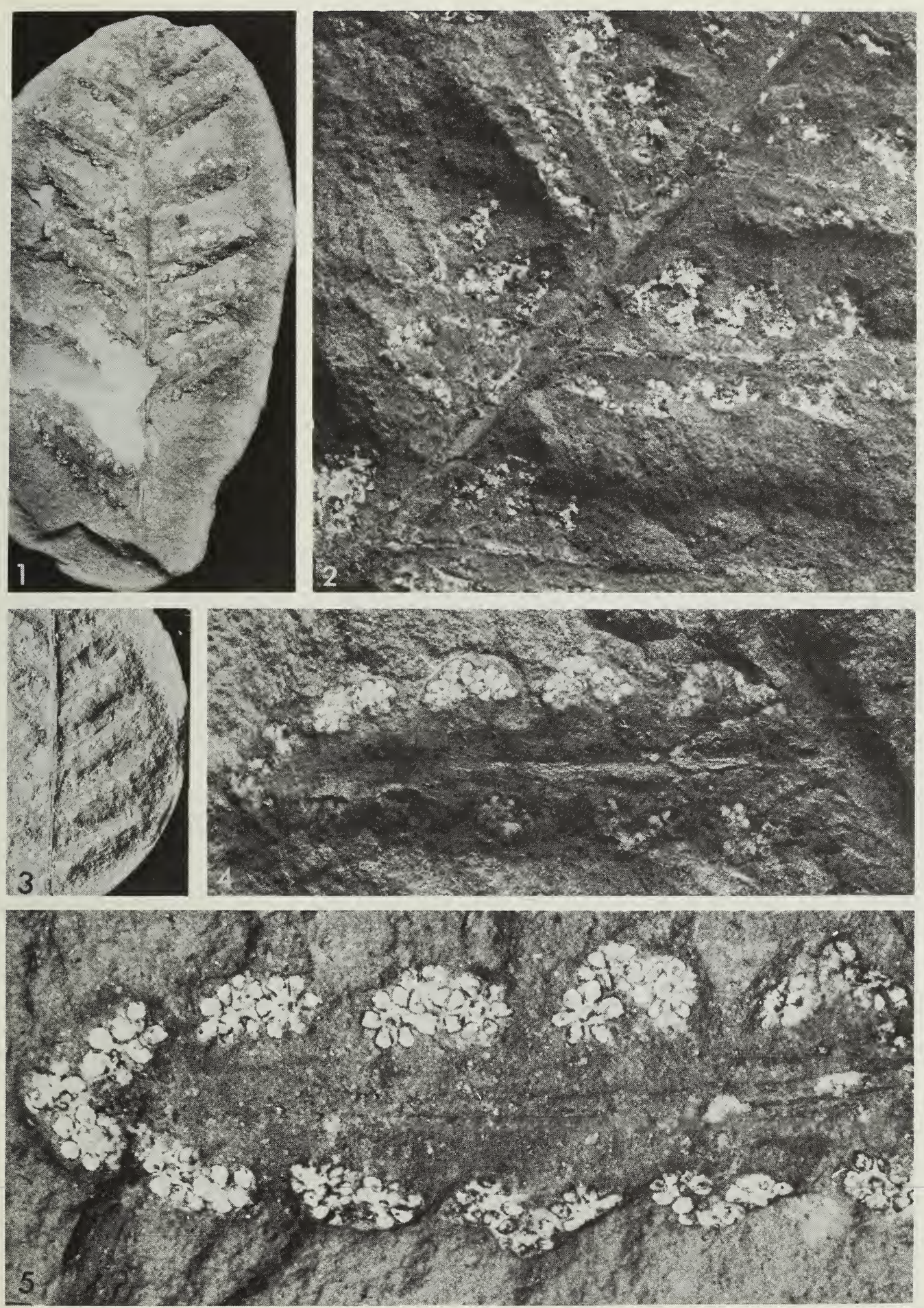


\section{PLATE 5}

Myriotheca scaberrima (Lesquereux, 1870) Sellards, 1902, p. 12

\section{Figure}

1 Specimen ISM $15728 \mathrm{~b}$; scale $1: 1$

2 Specimen ISM $15728 \mathrm{~b}$; scale $5: 1$

Spores of Myriotheca scaberrima (correlated with: Camptotriletes triangularis)

Figure

3 Specimen ISM 15728a; negative 8539; coordinates $139.5 \times 53.7$; size $34.1 \times 32.5 \mu \mathrm{m}$; scale $1000: 1$. Focus on the proximal surface of the spore.

4 Specimen ISM 15728a; negative 8541; same spore as Fig. 3 . Focus on the equator of the spore.

5 Specimen ISM 15728a; negative 8540; same spore as Fig. 3 . Focus on the distal surface of the spore.

6 Specimen ISM 15728a; negative 8538; coordinates $144.5 \times 53.6$; size $36.4 \times 34.1 \mu \mathrm{m}$; scale $1000: 1$. Focus on the distal surface of the spore.

7 Specimen ISM 15728a; scale 1200:1; scanning electron micrograph. 

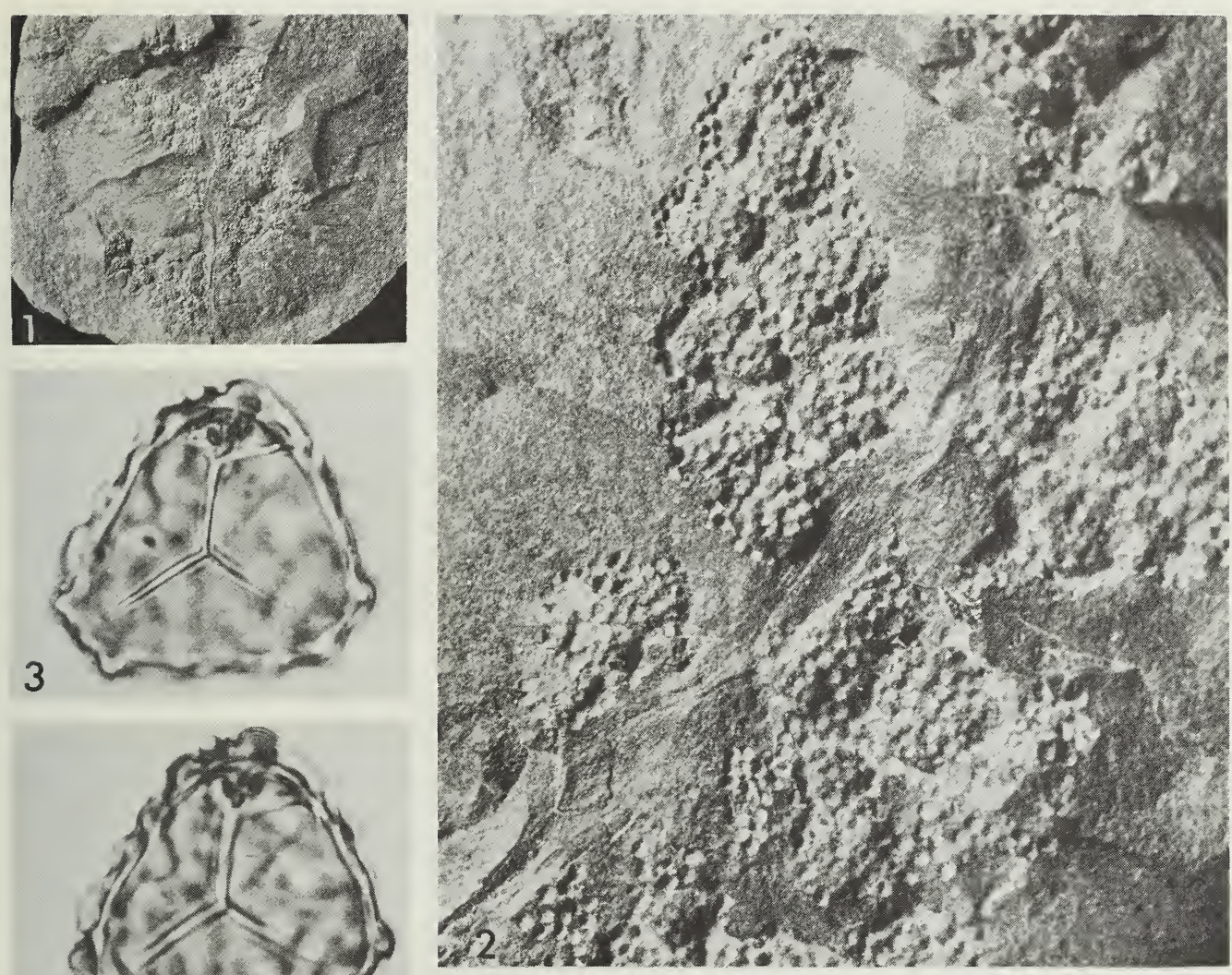

4
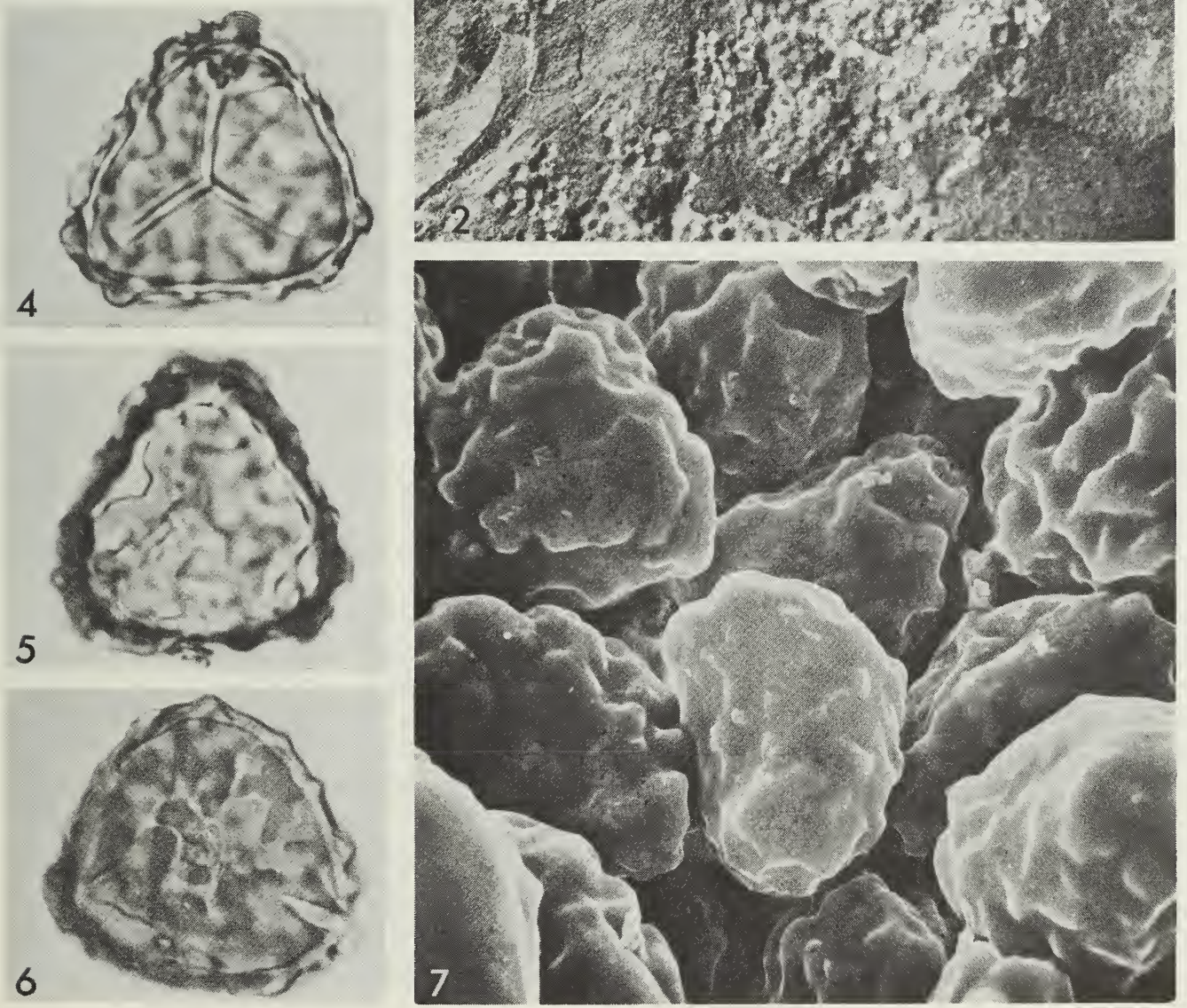
PLATE 6

Myriotheca arnoldi Pfefferkorn, sp. nov., p. 15

\section{Figure}

1 Specimen USNM 43714 B; paratype; scale $1: 1$

2 Specimen USNM 43714 B; paratype; scale $5: 1$

3 Specimen USNM 43714 A; paratype; scale 5:1

4 Specimen ISM 15383b; holotype; scale 1:1

5 Specimen ISM 15383a; holotype; scale $1: 1$

6 Specimen ISM 15383b; holotype; scale 5:1

Spores of Myriotheca arnoldi (correlated with: ? Punctatisporites, ? Calamospora)

Figure

7 Specimen USNM 43714 B; scale 250:1; scanning electron micrograph.

8 Specimen ISM 15383b; scale 500:1; scanning electron micrograph.

9 Specimen ISM 15383a; negative 8558; coordinates $123.3 \times 48.8$; size $87.8 \times 74.8 \mu \mathrm{m}$; scale $500: 1$ 

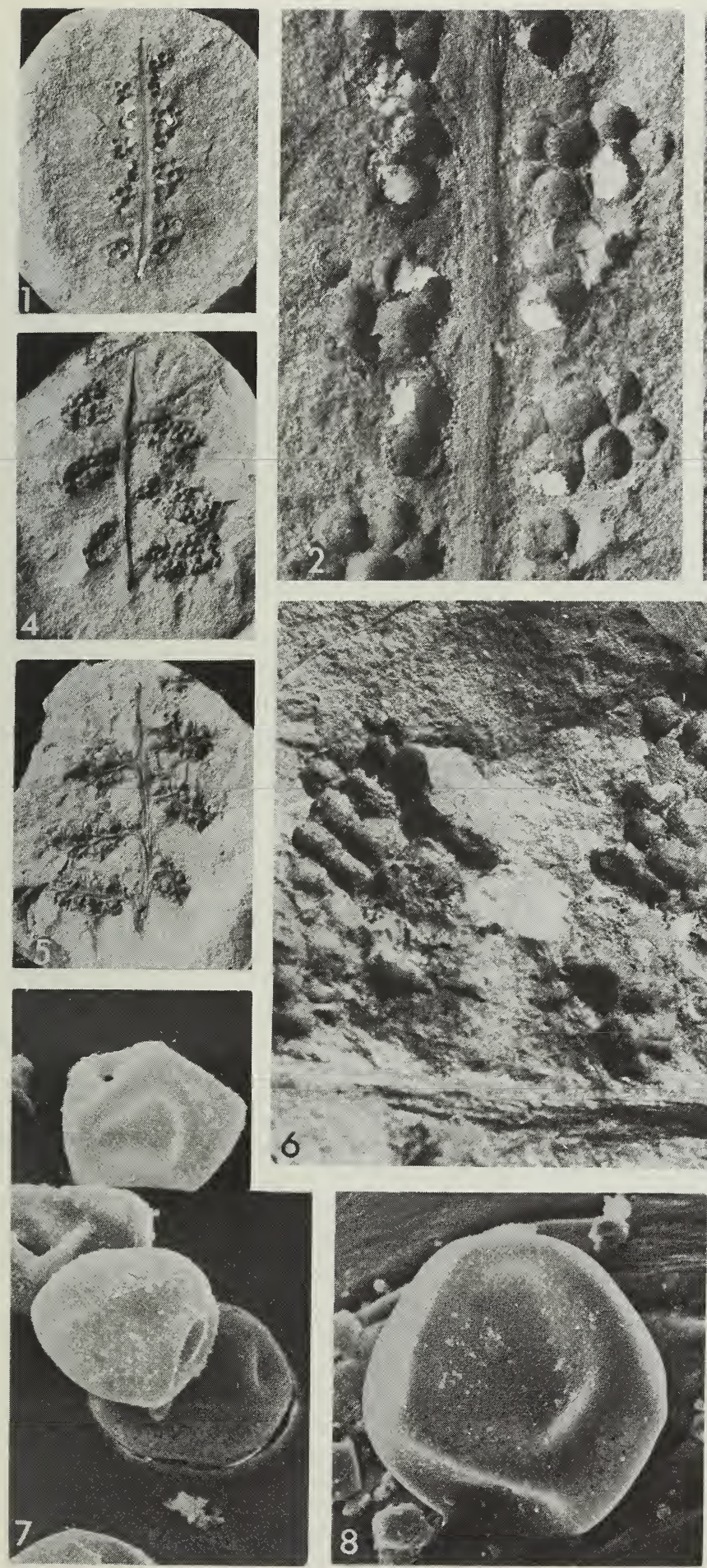
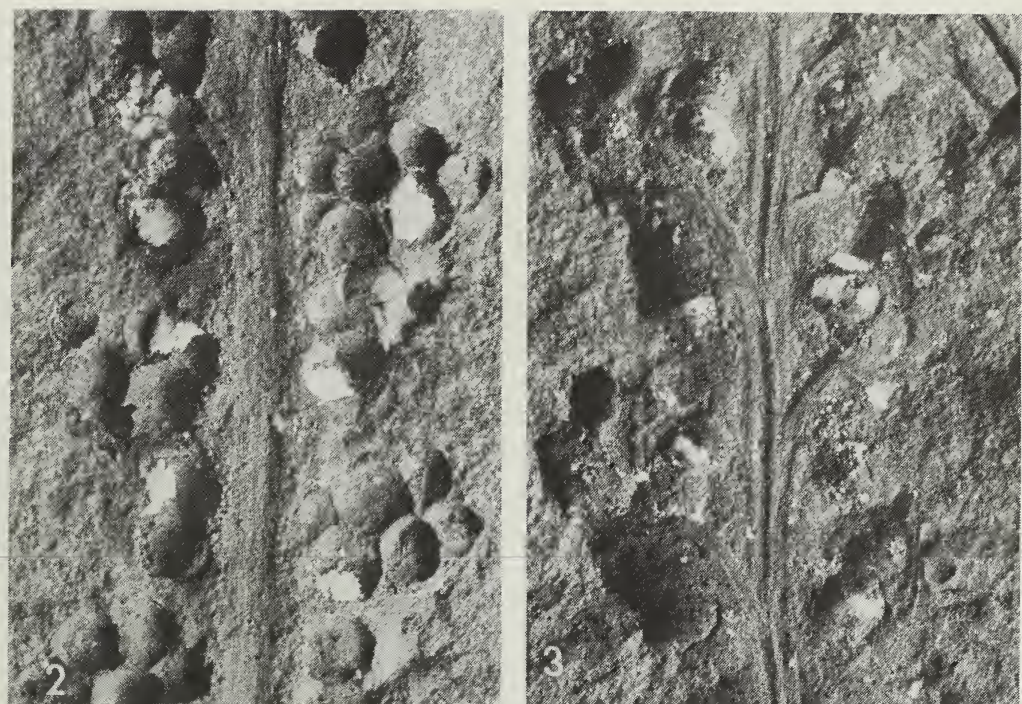

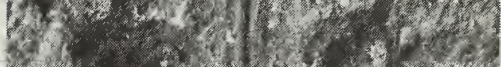

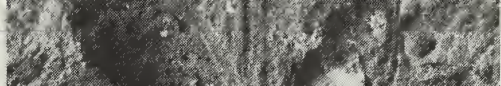

-, 1.27 32n-112

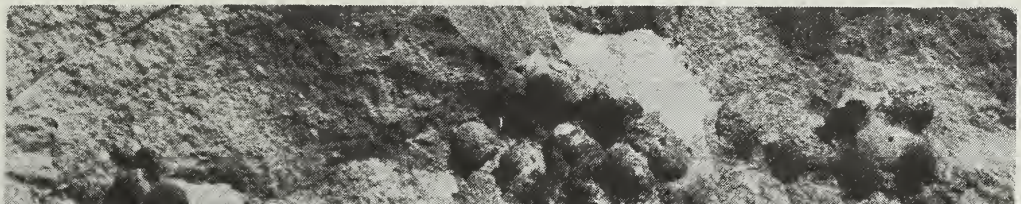

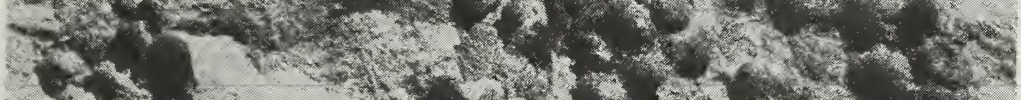

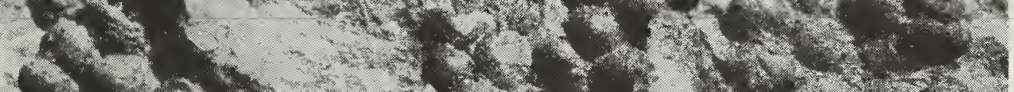

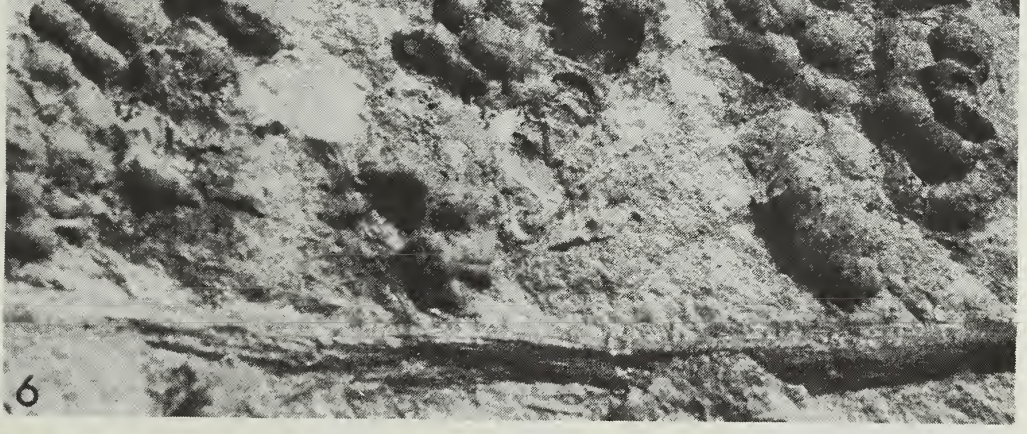




\section{PLATE 7}

\section{Corynepteris (ex Alloiopteris) cf. erosa}

(Gutbier, 1843) Kidston, 1887, p. 16

Figure

1 Specimen C 10814; scale 1:1; under xylol.

2 Specimen C 10814; scale 5:1; under xylol; arrow points at aphleboid pinnule.

Spores of Corynepteris (ex Alloiopteris) cf. erosa (correlated with: Apiculatisporis setulosus)

Figure

3 Specimen C 10814; scale 1000:1; scanning electron micrograph.

4 Specimen C 10814; scale 500:1; scanning electron micrograph.

5 Specimen C 10814; negative 8527; coordinates 144.5 x 45.0 ; size $40.0 \mathrm{x}$ $38.4 \mu \mathrm{m}$; scale 1000:1

6 Specimen C 10814 ; negative 8521 ; coordinates $144.5 \times 45.0$; size $40.0 \times$ $38.4 \mu \mathrm{m}$; scale 1000:1. Focus on margin. 

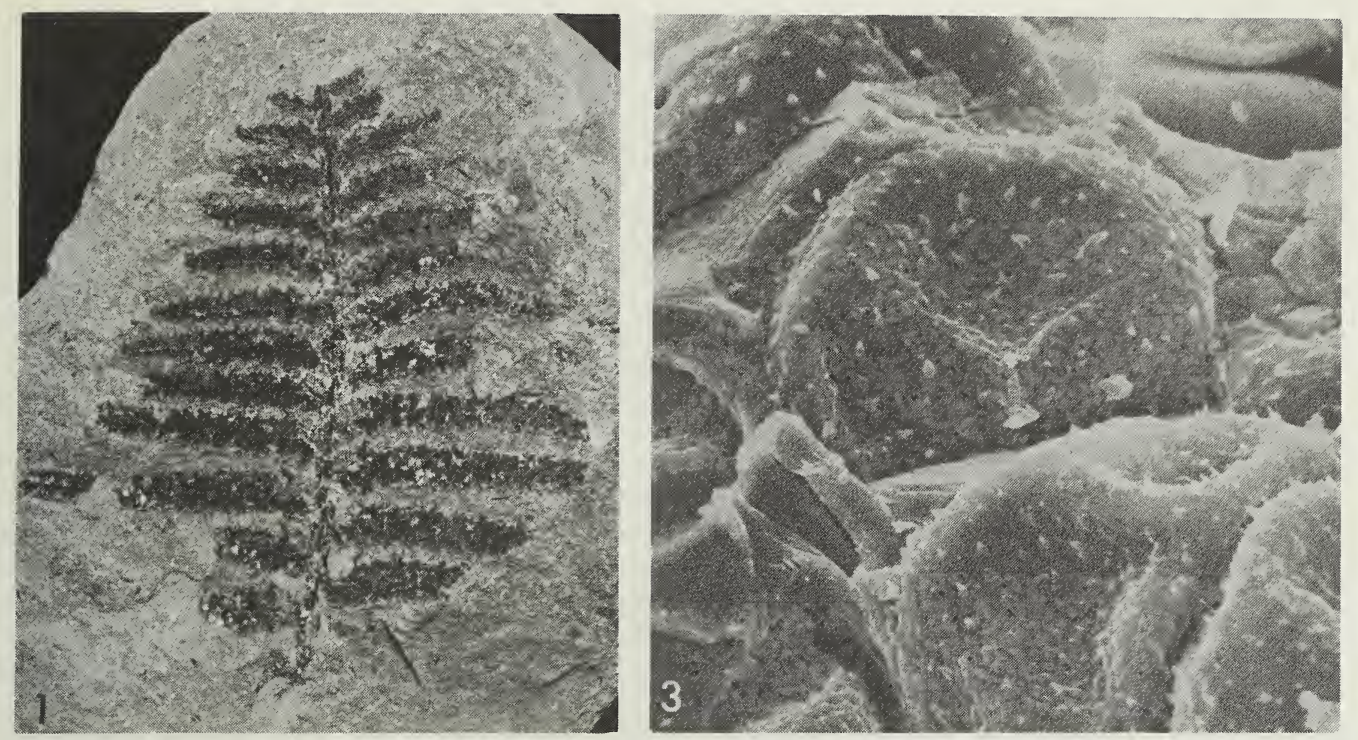

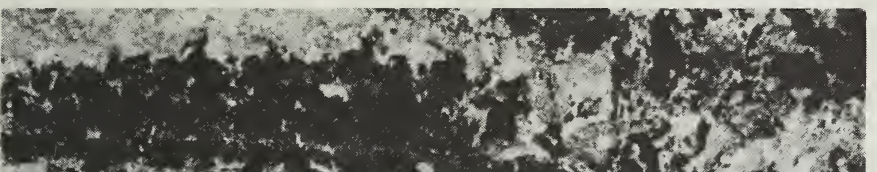

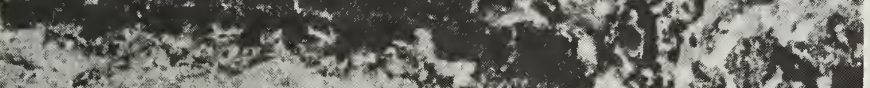

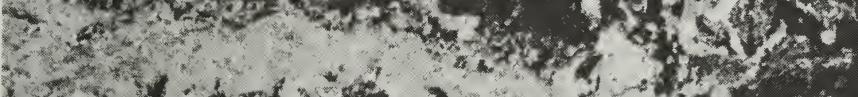

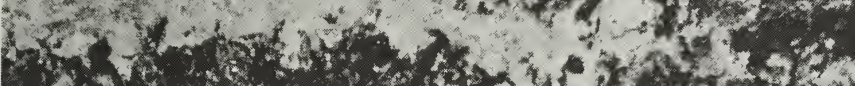

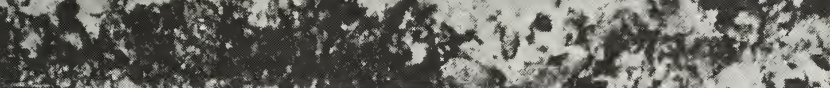

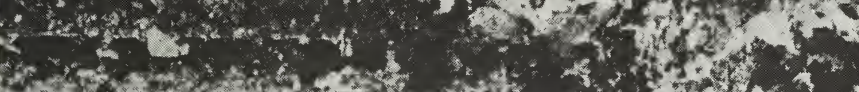

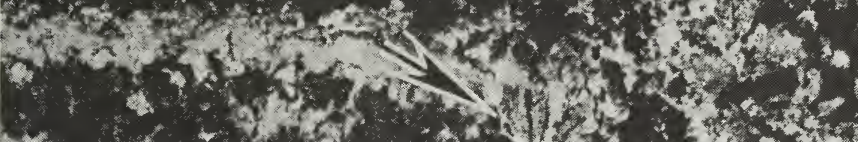

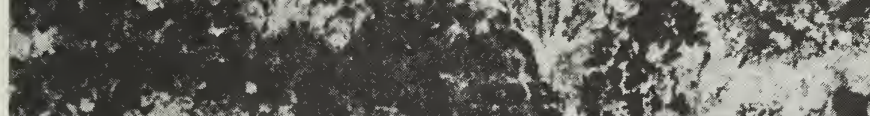

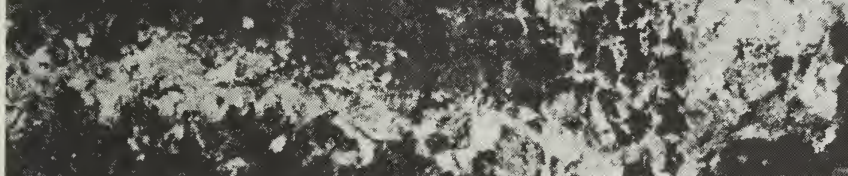

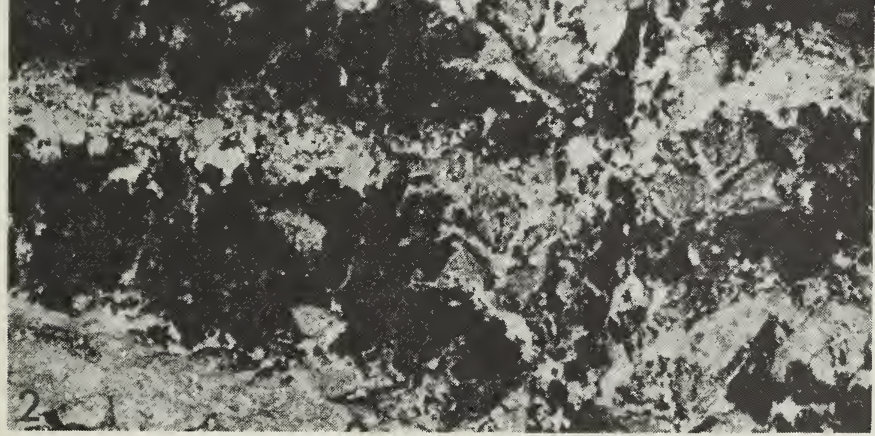
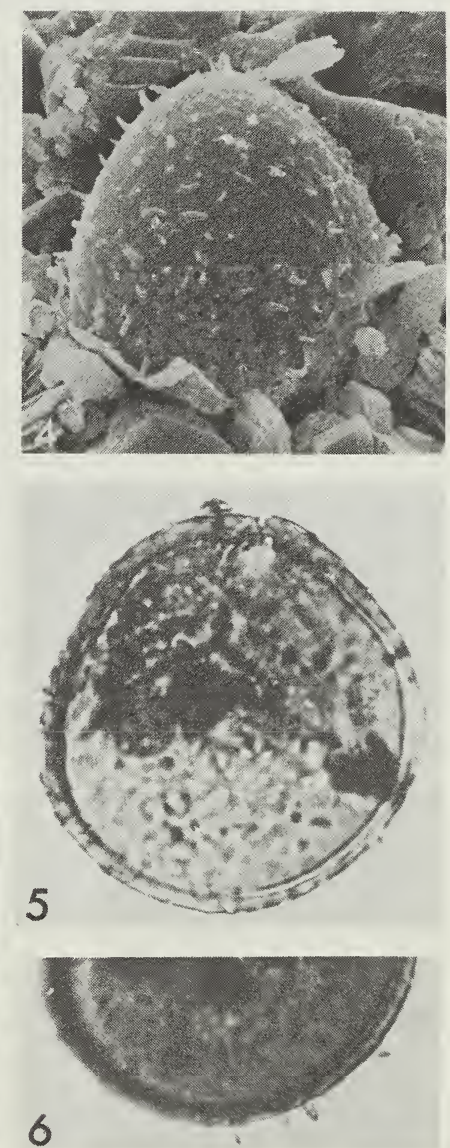
PLATE 8

Asterotheca (ex Pecopteris) species 1 and 2, p. 17

Figure

1 A. sp. 1; specimen PP 15338; scale $1: 1$; under xylol.

2 Specimen PP 15338; scale 5:1; under xylol.

3 A. sp. 2; specimen USNM 14212; scale 1:1; under xylol.

4 Specimen USNM 14212; scale 5:1; under xylol.

Spores of Asterotheca sp. 1 and sp. 2 (correlated with Laevigatosporites minutus)

Figure

$5 \quad$ A. sp. 1; specimen PP 15338; negative 8709; coordinates $141.0 \times 43.9$; size 19.5 × $10.4 \mu \mathrm{m}$; scale 1000:1

$6 \quad$ A. sp. 2; specimen USNM 14212; negative 8589; coordinates $135.9 \times 27.4$; size $19.5 \times 12.0 \mu \mathrm{m}$; scale 1000:1.

7 A. sp. 2; specimen USNM 14212; scale $1000: 1$; scanning electron micrograph. 

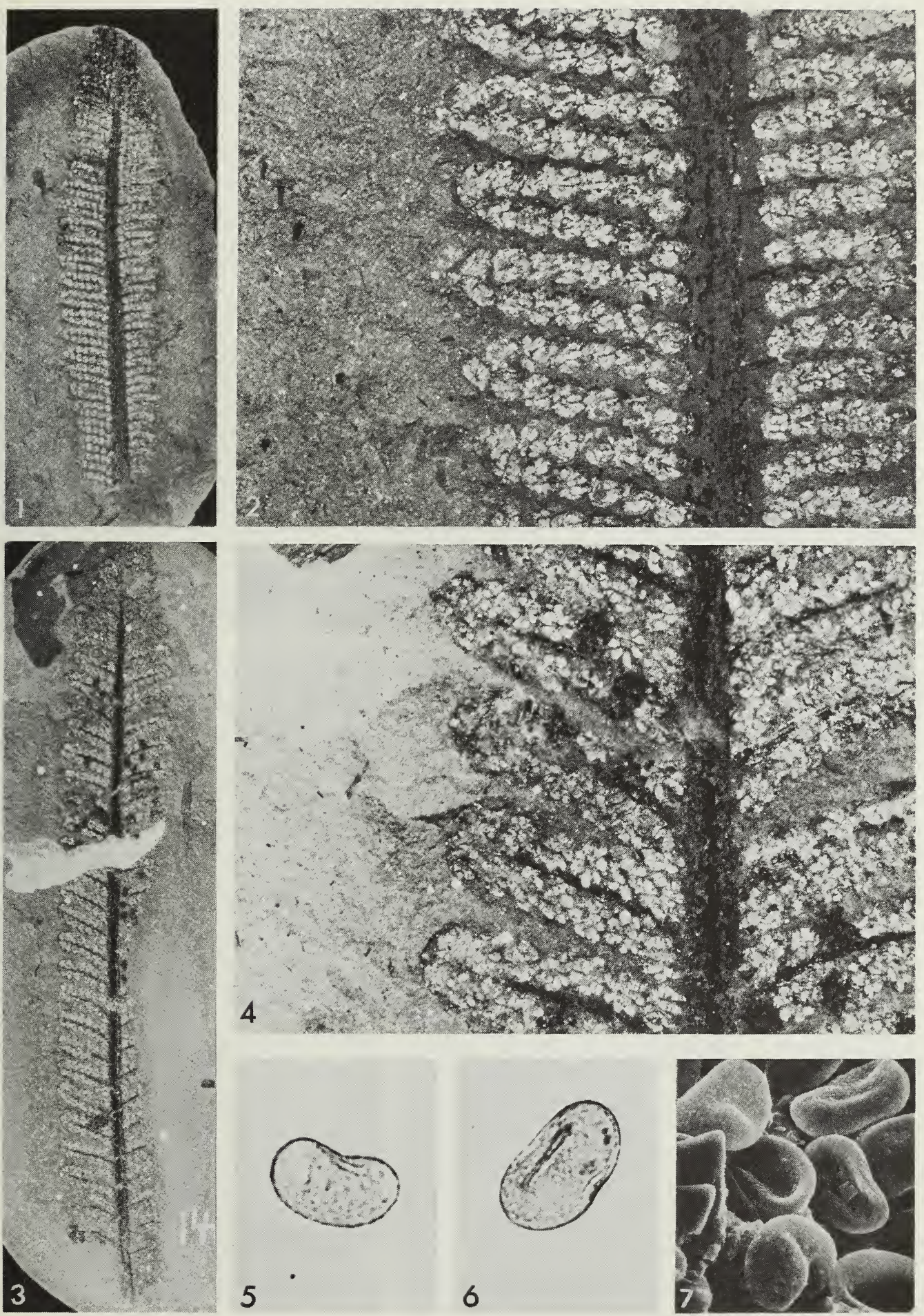
PLATE 9

Asterotheca (ex Pecopteris) sp. 3, p. 17

Figure

$1 \quad$ Specimen C 10797; scale 5:1

2 Specimen C 10797; scale 1:1

Spores of Asterotheca (ex Pecopteris) sp. 3 (correlated with Punctatisporites minutus)

\section{Figure}

3 Specimen C 10797; scale 1200:1; scanning electron micrograph.

4 Specimen C 10797; scale 1200:1; scanning electron micrograph.

5 Specimen C 10797; negative 8711; coordinates $129.0 \times 45.3$; size $16.6 \times$ $12.7 \mu \mathrm{m}$; scale 1000:1

6 Specimen C 10797; negative 8714; coordinates $130.4 \times 35.1$; size $16.3 \times$ $15.0 \mu \mathrm{m}$; scale 1000:1 

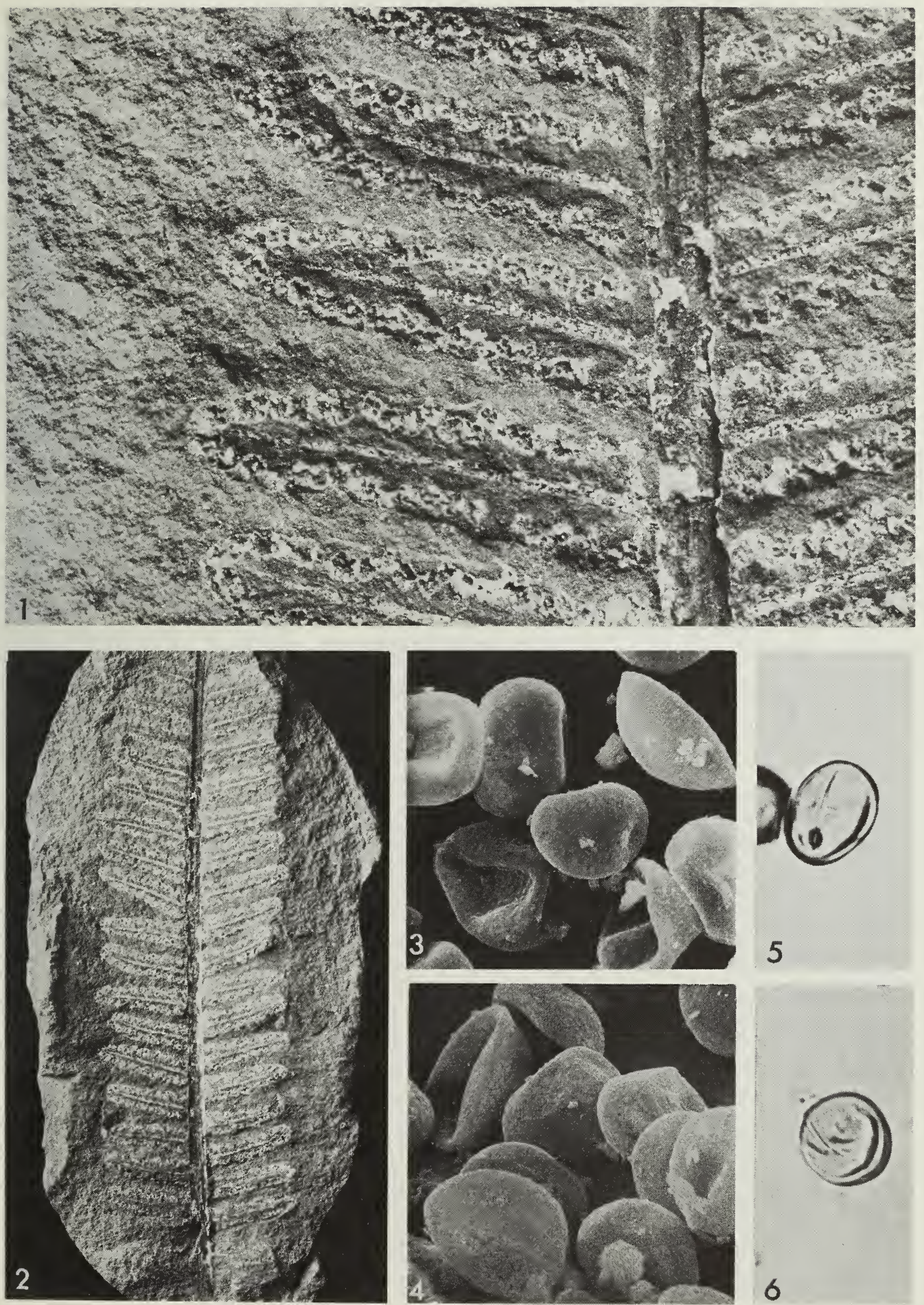
PLATE 10

Asterotheca (ex Pecopteris) sp. 4, p. 17

\section{Figure}

1 Specimen USNM 13288; scale 5:1

2 Specimen USNM 13288; scale $1: 1$

Spores of Asterotheca (ex Pecopteris) sp. 4 (correlated with Punctatisporites minutus)

Figure

3 Specimen USNM 13288; scale 1000:1; scanning electron micrograph.

$4 \quad$ Specimen USNM 13287 (counterpart of 13288); negative 8588; coordinates $130.9 \times 49.4$; size $16.3 \times 15.9 \mu \mathrm{m}$; scale $1000: 1$ 


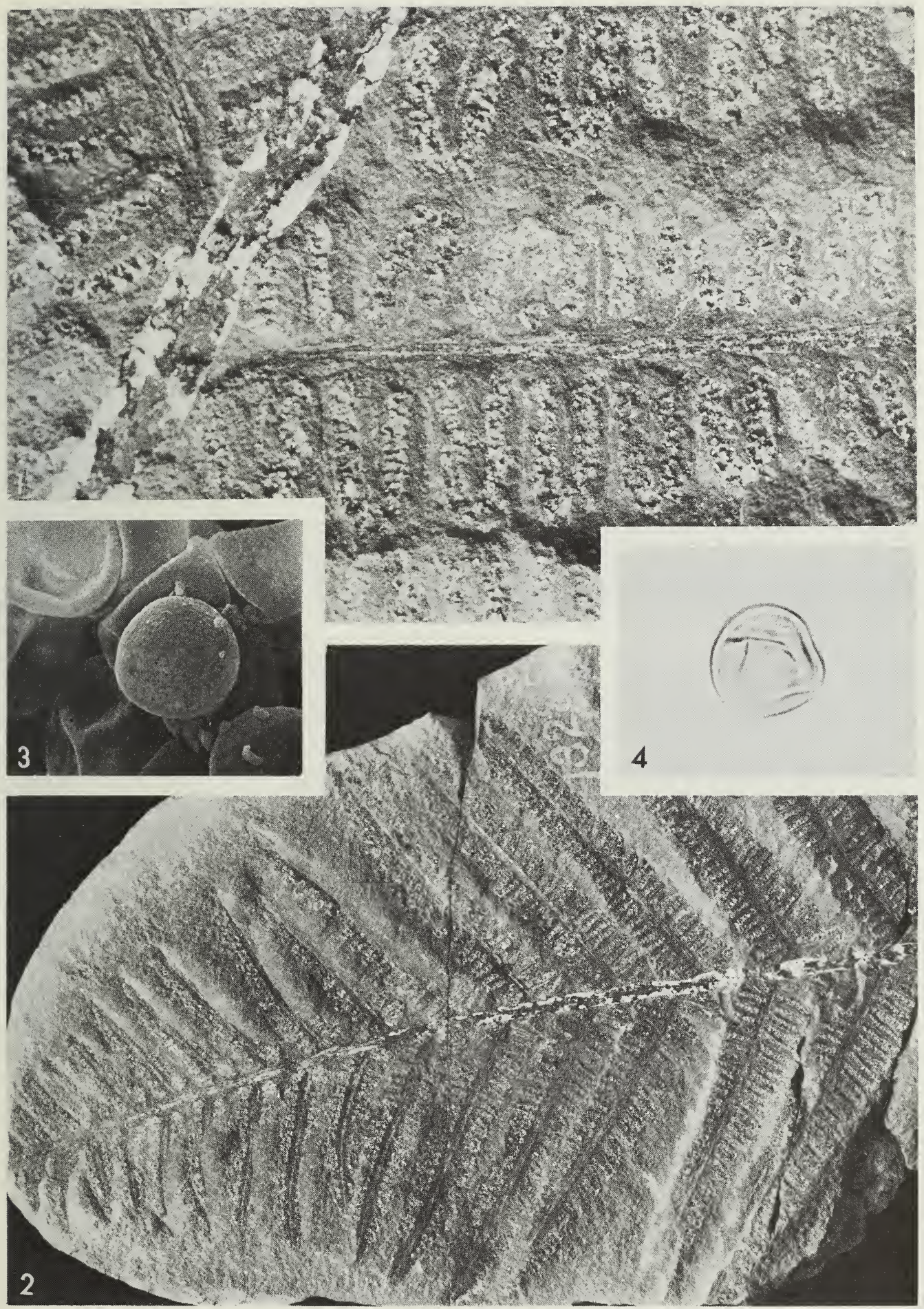


PLATE 11

Asterotheca (ex Pecopteris) cf. miltoni, p. 19

Figure

$1 \quad$ Specimen ISM 15382; scale $5: 1$

2 Specimen ISM 15382; scale $1: 1$

Spore of Asterotheca (ex $\underline{\text { Pecopteris) }}$ ) ff $\underline{\text { miltoni }}$ (correlated with Cyclogranisporites aureus)

Figure

3 Specimen ISM 15382; negative 8534; coordinates $123.4 \times 48.3$; size $50.1 \times 35.8 \mu \mathrm{m}$; scale $1000: 1$

Asterotheca (ex Pecopteris) sp. 3, p. 17 (see plate 9)

Figure

4 Spore mass of specimen C 10797; slide 1, negative 8563 ; scale $500: 1$ 

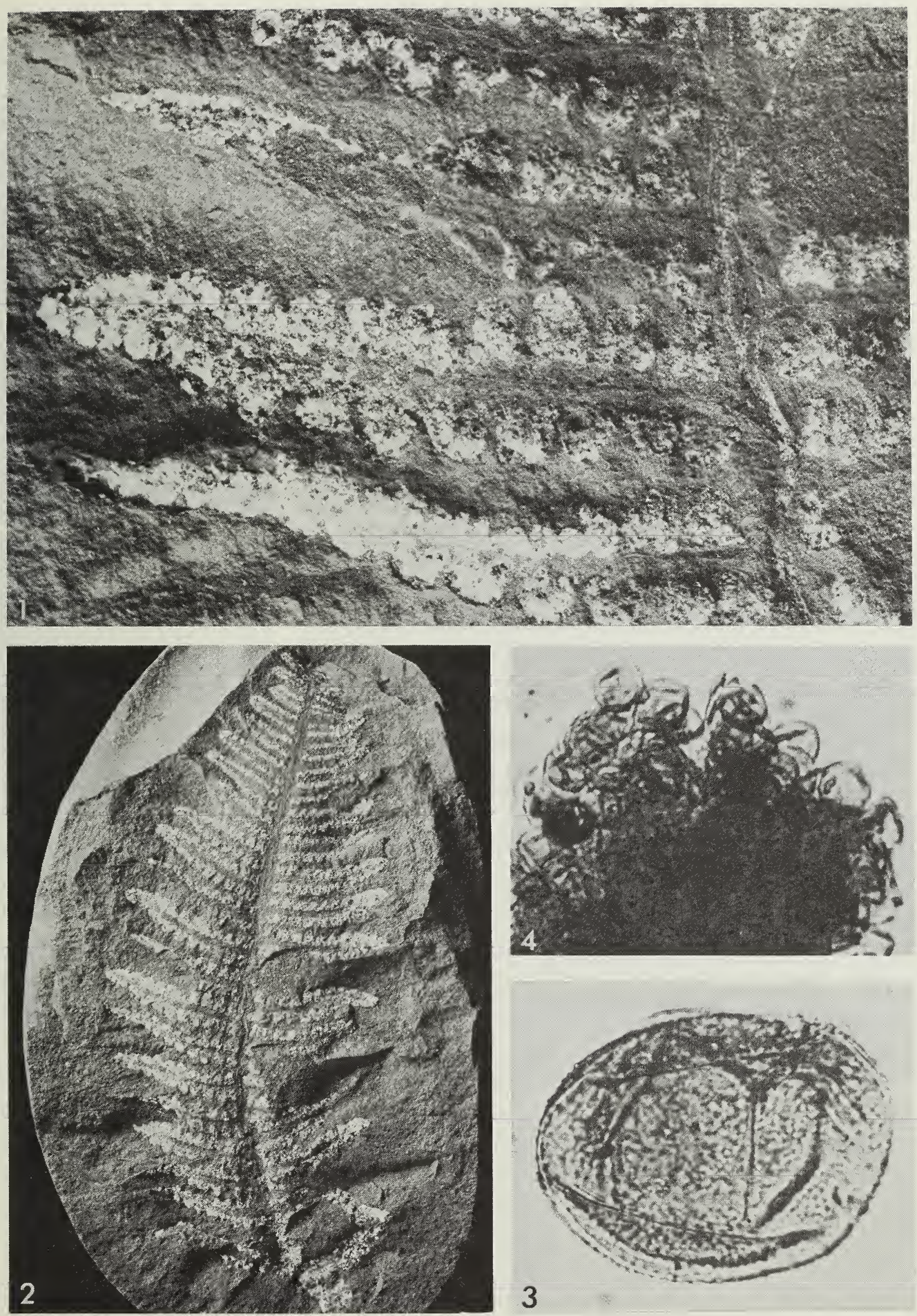

3

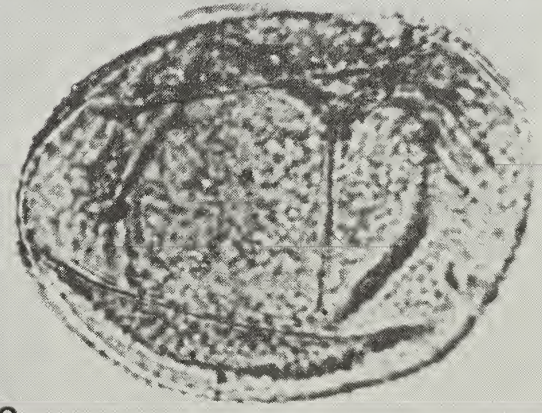


PLATE 12

? Scolecopteris (ex Pecopteris) sp. 1 and 2, p. 21

Figure

1 ? $\underline{\text { S. }}$ sp. 2; specimen C 10803; scale $1: 1$

2 ? 2 . sp. 2; specimen C 10803 ; scale $5: 1$

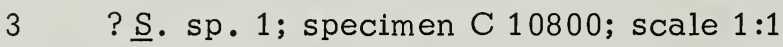

4 ? S. sp. 1 ; specimen C 10800 ; scale $5: 1$

Spores of ? Scolecopteris (ex Pecopteris) sp. 1 (correlated with Punctatisporites sp.)

Figure

5 Specimen C 10800; negative 8625; coordinates $138.4 \times 27.0$; size $21.8 \times$ $19.5 \mu \mathrm{m}$; scale $1000: 1$

6 Specimen C 10800; scale 1200:1; scanning electron micrograph.

Spores of ? Scolecopteris (ex Pecopteris) sp. 2 (correlated with Laevigatosporites globosus)

Figure

7 Specimen C 10803; scale 3000:1; scanning electron micrograph.

8 Specimen C 10803; scale 1200:1; scanning electron micrograph.

9 Specimen C 10803; negative 8745; coordinates $135.5 \times 34.5$; size $21.2 \times$ $19.5 \mu \mathrm{m}$; scale 1000:1. Focus on proximal surface of spore.

10 Specimen C 10803; negative 8708; coordinates $137.0 \times 40.1$; size $22.8 \times$ $22.4 \mu \mathrm{m}$; scale 1000:1. Focus on equator of spore. 

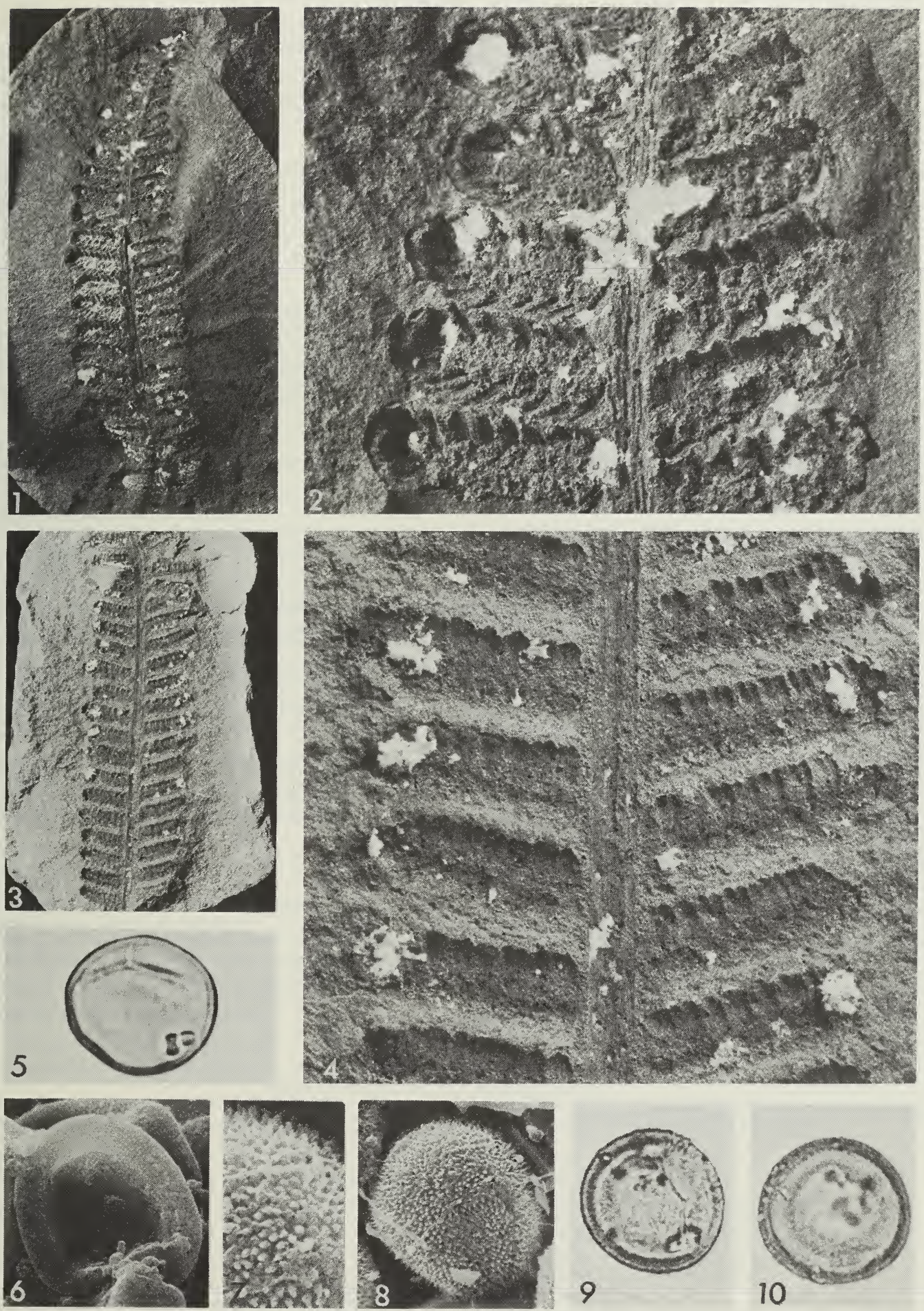
Illinois State Geological Survey Circular 463

56 p., 4 tables, 9 figs., 12 plates, 2500 cop., 1971 Urbana, Illinois 61801 
JOHN C. FRYE, Ph.D., D.Sc., Chief

Hubert E. Risser, Ph.D., Assistant Chief

G. R. Eadie, M.S., E.M., Administrative Engineer

Velda A. Millard, Fiscal Assistant to the Chief

Helen E. McMorris, Secretary to the Chief

Mary M. Sullivan, Research Assistant

GEOLOGICAL GROUP

Jack A. Simon, M.S., Principal Geologist

M. L. Thompson, Ph.D., Principal Research Geologist R. E. Bergstrom, Ph. D., Coordinator, Environmental Geology (on leave) Frances H. Alsterlund, A.B., Research As sociate

COAL

M. E. Hopkins, Ph.D., Geologist and Head

Harold J. Gluskoter, Ph.D., Geologist

William H. Smith, M.S., Geologist

Neely H. Bostick, Ph.D., Associate Geologist

Kenneth E. Clegg, M.S., Associate Geologist

Heinz H. Damberger, D.Sc., Associate Geologist

Russel A. Peppers, Ph.D., Associate Geologist

Roger B. Nance, M.S., Assistant Geologist

Kenneth R. Cope, B.S., Research Assistant

\section{STRATIGRAPHY AND AREAL GEOLOGY}

Charles Collinson, Ph.D., Geologist and Head

Elwood Atherton, Ph.D., Geologist

T. C. Buschbach, Ph.D., Geologist

Herbert D. Glass, Ph.D., Geologist

Lois S. Kent, Ph.D., As sociate Geologist

Jerry A. Lineback, Ph.D., Associate Geologist

David L. Gross, Ph.D., Assistant Geologist

Alan M. Jacobs, Ph.D., Assistant Geologist

Michael L. Sargent, M.S., Assistant Geologist

Matthew J. Avcin, M.S., Research Assistant

Mildred R. Newhouse, Technical Assistant

ENGINEERING GEOLOGY AND TOPOGRAPHIC MAPPING

W. Calhoun Smith, Ph.D., Geologist in charge

Paul B. DuMontelle, M.S., As sociate Geologist

Robert E. Cole, B.S., Research Assistant

CLAY RESOURCES AND CLAY MINERAL TECHNOLOGY

W. Arthur White, Ph.D., Geologist and Head

Bruce F. Bohor, Ph.D., Associate Geologist

Cheryl W. Adkisson, B.S., Research Assistant

\section{GEOLOGICAL RECORDS}

Vivian Gordon, Head

Hannah Kistler, Supervisory Assistant

Elizabeth A. Anderson, Technical Assistant

Betty C. Cox, Technical Assistant

Joann L. Graves, Technical Assistant

Diane A. Heath, B.A., Technical Assistant

Coradel R. Little, A.B., Technical Assistant

Connie L. Maske, B.A., Technical Assistant

Elizabeth Speer, Technical Assistant
GROUND-WATER GEOLOGY AND GEOPHYSICAL EXPLORATION Robert E. Bergstrom, Ph.D., Geologist and Head Merlyn B. Buhle, M.S., Geologist

Keros Cartwright, M.S., Associate Geologist

George M. Hughes, Ph.D., As sociate Geologist John P. Kempton, Ph.D., Associate Geologist Leon R. Follmer, Ph.D., Assistant Geologist Manoutchehr Heidari, Ph.D., Assistant Engineer Paul C. Heigold, Ph.D., Assistant Geophysicist Kemal Piskin, M.S., Assistant Geologist Philip C. Reed, A.B., Assistant Geologist Frank B. Sherman, Jr., M.S., Assistant Geologist Ross D. Brower, M.S., Jr. Assistant Geologist Jean I. Larsen, M.A., Jr. Assistant Geologist

Joan E. Buehler, A. M., Research Assistant George P. Zielinski, Technical Assistant

\section{OIL AND GAS}

Donald C. Bond, Ph.D., Head

Lindell H. Van Dyke, M.S., Geologist

Thomas F. Lawry, B.S., Associate Petroleum Engineer

R. F. Mast, M.S., Associate Petroleum Engineer

Wayne F. Meents, Associate Geological Engineer David L. Stevenson, M.S., Associate Geologist Hubert M. Bristol, M.S., Assistant Geologist Richard H. Howard, M.S., Assistant Geologist Jacob Van Den Berg, M.S., Assistant Geologist Nancy J. Harper, Technical Assistant Marjorie E. Melton, Technical Assistant

\section{INDUSTRIAL MINERALS}

James C. Bradbury, Ph.D., Geologist and Head

James W. Baxter, Ph.D., Geologist

Richard D. Harvey, Ph.D., Geologist

Norman C. Hester, Ph.D., Assistant Geologist

George M. Wilson, M.S., Assistant Geologist

GEOLOGICAL SAMPLES LIBRARY

Robert W. Frame, Superintendent

J. Stanton Bonwell, Supervisory As sistant

Charles J. Zelinsky, Supervisory Assistant

Eugene W. Meier, Technical Assistant

Jannice P. Richard, Clerk-Stenographer II

CHEMICAL GROUP

G. Robert Yohe, Ph.D., Senior Chemist

Thelma J. Chapman, B.A., Research Assistant
Principal Chemist

N. F. Shimp, Ph.D., Coordinator, Environmental Research Anita E. Bergman, B.S., Technical Assistant

\section{GEOCHEMISTRY}

G. C. Finger, Ph.D., Acting Head

R. J. Helfinstine, M.S., Mechanical Engineer and Head

H. P. Ehrlinger III, M.S., E.M., Assoc. Minerals Engineer John M. Masters, M.S., Assistant Mineralogist

Lee D. Arnold, B.S., Research Assistant

Walter E. Cooper, Technical As sociate

Robert M. Fairfield, Supervisory Assistant

Jimmie D. Cooper, Technical Assistant

John P. McClellan, Technical Assistant (on leave)

Edward A. Schaede, Technical Assistant (on leave)
Donald R. Dickerson, Ph.D., Organic Chemist Josephus Thomas, Jr., Ph.D., Physical Chemist Richard H. Shiley, M.S., Associate Organic Chemist Robert R. Frost, Ph.D., Assistant Physical Chemist

Ralph S. Boswell, Technical Assistant

(Chemical Group continued on next page) 


\section{ANALYTICAL CHEMISTRY}

Neil F. Shimp, Ph.D., Chemist and Head William J. Armon, M.S., Associate Chemist Charles W. Beeler, M.A., Associate Chemist Rodney R. Ruch, Ph.D., Associate Chemist John A. Schleicher, B.S., Associate Chemist Larry R. Camp, B. S., Assistant Chemist Dennis D. Coleman, M.S., Assistant Chemist David B. Heck, B.S., Assistant Chemist
L. R. Henderson, B.S., Assistant Chemist F. E. Joyce Kennedy, Ph.D., Assistant Chemist Lawrence B. Kohlenberger, B.S., Assistant Chemist John K. Kuhn, B.S., Assistant Chemist Joan D. Hauri, B.A., Special Research Assistant Fei-fei C. Lee, M.S., Special Research Assistant Paul E. Gardner, Technical Assistant George R. James, Technical Assistant

MINERAL ECONOMICS GROUP

Hubert E. Risser, Ph.D., Principal Mineral Economist

W. L. Busch, A.B., Economic Analyst Robert L. Major, M.S., Assistant Mineral Economist Irma E. Samson, Clerk Typist II

ADMINISTRATIVE GROUP

George R. Eadie, M.S., E.M., Head

Paula A. Grabenstein, B.S., Research Assistant

\section{EDUCATIONAL EXTENSION}

David L. Reinertsen, A. M., Geologist and Acting Head William E. Cote, M.S., Assistant Geologist

Dwain G. Berggren, M.A., Jr. Assistant Geologist

Myrna M. Killey, B.A., Research Assistant

\section{PUBLICATIONS}

Betty M. Lynch, B.Ed., Technical Editor

Mary Ann Noonan, A.M., Technical Editor

Jane E. Busey, B.S., Assistant Technical Editor

Dorothy Rae Weldon, Editorial Assistant

Marie L. Martin, Geologic Draftsman

Illona Sandorfi, Assistant Geologic Draftsman

Patricia A. Whelan, B.F.A., Asst. Geologic Draftsman William Dale Farris, Scientific Photographer

Dorothy H. Huffman, Technical Assistant

\section{GENERAL SCIENTIFIC INFORMATION}

Peggy H. Schroeder, B.A., Research As sistant

Florence J. Partenheimer, Technical Assistant

\section{SPECIAL TECHNICAL SERVICES}

Ernest R. Adair, Technical Assistant David B. Cooley, Administrative Assistant Wayne W. Nofftz, Distributions Supervisor Glenn G. Poor, Research As sociate (on leave) Merle Ridgley, Instrument Specialist James E. Taylor, Automotive Mechanic Donovon M. Watkins, Technical Assistant

\section{EMERITI}

J. S. Machin, Ph.D., Principal Chemist

O. W. Rees, Ph.D., Principal Research Chemist

W. H. Voskuil, Ph.D., Principal Mineral Economist

A. H. Bell, Ph.D., Geologist

George E. Ekblaw, Ph.D., Geologist

H. W. Jackman, M.S.E., Chemical Engineer

J. E. Lamar, B.S., Geologist

L. D. MoVicker, B.S., Chemist

Enid Townley, M.S., Geologist

Lester L. Whiting, M.S., Geologist

H. B. Willman, Ph.D., Geologist

Juanita Witters, M.S., Physicist

B. J. Greenwood, B.S., Mechanical Engineer

\section{FINANCIAL OFFICE}

Velda A. Millard, in charge

Marjorie J. Hatch, Account Technician I

Pauline Mitchell, Account Technician I

Virginia C. Smith, B.S., Account Technician I

\section{CLERICAL SERVICES}

Nancy J. Hansen, Secretary I

Hazel V. Orr, Clerk-Stenographer III

Mary K. Rosalius, Clerk-Stenographer II

Lucy Wagner, Clerk-Stenographer II

Jane C. Washburn, Clerk-Stenographer II

Francie W. Doll, Clerk-Stenographer I

Janette L. Hall, Clerk-Stenographer I

Theresa J. Lamendola, Clerk-Stenographer I

Edna M. Yeargin, Clerk-Stenographer I

JoAnn L. Lynch, Clerk-Typist II

Judith Ann Muse, Clerk-Typist II

Pauline F. Tate, Clerk-Typist II

\section{TECHNICAL RECORDS}

Miriam Hatch, Supervisor

Carol E. Fiock, Technical Assistant

Hester L. Nesmith, B.S., Technical Assistant

\section{LIBRARY}

Mary P. Krick, M.S., Geological Librarian

Linda K. Clem, B.S., Assistant Librarian

\section{RESEARCH AFFILIATES AND CONSULTANTS}

Richard C. Anderson, Ph.D., Augustana College

W. F. Bradley, Ph.D., University of Texas

David A. Castillon, M.A., Lincoln College John P. Ford, Ph.D., Eastern Illinois University Donald L. Graf, Ph.D., University of Illinois S. E. Harris, Jr., Ph.D., Southern Illinois University W. Hilton Johnson, Ph.D., University of Illinois Harry V. Leland, Ph. D., University of Illinois A. Byron Leonard, Ph.D., University of Kansas Lyle D. McGinnis, Ph. D., Northern Illinois University I. Edgar Odom, Ph.D., Northern Illinois University T. K. Searight, Ph.D., Illinois State University George W. White, Ph.D., University of Illinois 

CIRCULAR 463

ILLINOIS STATE GEOLOGICAL SURVEY URBANA 61801 